\title{
Interpreting the unconventional U.S. monetary policy of 2007-09*
}

\author{
Ricardo Reis \\ Columbia University
}

October 2009

\begin{abstract}
This paper reviews the unconventional U.S. monetary policy responses to the financial and real crises of 2007-09. It catalogues these policies into three groups: interestrate policy, quantitative policy, and credit policy. To interpret interest-rate policy, it compares the Federal Reserve's actions with the literature on optimal policy in a liquidity trap. This comparison suggests that policy has been in the direction suggested by theory, but it has not gone far enough. To interpret quantitative policy, it reviews the determination of inflation under different policy regimes. The main danger for inflation coming from the current actions is that the Federal Reserve may lose its independence in choosing monetary policies, while a beneficial side-effect of the crisis is that the Friedman rule can be implemented by paying interest on reserves. To interpret credit policy, it presents a new model of capital market imperfections and their interaction with real investment decisions with different financial institutions and a role for legacy assets, mark-to-market, and leverage. The model suggests that providing credit to traders in securities markets is a more effective response to a financial crisis than it is to extend credit to the originators of loans.
\end{abstract}

\footnotetext{
*I am grateful to Tim Besley, Don Kohn, Elmar Mertens, Ed Nelson, Roberto Perli, Adam Posen, David Romer, Lars Svensson, Mike Woodford, and the conference participants for useful discussions, and to Nicolas Crouzet for excellent research assistance. Contact: rreis@columbia.edu.
} 


\section{Introduction}

The last two years have been an exciting time to be a student of monetary policy and central banking. Variability in the data is what allows us to learn about the world, and variability has not been in short supply in the United States with wide swings in asset prices, threats to financial stability, concerns about regulation, sharply rising unemployment, and a global recession. At the same time, these have been difficult times to be a central banker. The limited tools at the disposal of the Federal Reserve have been hardly sufficient to put out so many fires, and many of the challenges have caught central bankers unprepared for what not so long ago seemed highly improbable.

The goal of this paper is to review the Federal Reserve's actions and interpret them in the light of economic theory. Interpret is the operative word here, since trying to describe and evaluate all that has happened would be tasks doomed to fail. On the one hand, so much has already happened that it would take one (or many) books to describe and account for it all. On the other hand, we are still in the midst of the crisis, so that any assessment runs the risk of quickly becoming obsolete. As a result, I will avoid, as far as I can, making pronouncements on what policies seem right or wrong, even with the benefit of hindsight, and I will also not give a comprehensive account of all the events and policies. The more modest ambition of this paper is to provide an early summary of what has been monetary policy's reaction to the crisis, to interpret this reaction using economic theory, and to raise some of the questions that come with it.

I start in section 2 with brief accounts of the crisis and of the Federal Reserve's behavior, leading to a grouping of monetary policy into three categories. The first category is interestrate policy, and it concerns the targets that the Federal Reserve sets for some interest rates. Figure 1 illustrates the recent changes by plotting three key interest rates targeted by the Federal Reserve over the last twenty years. Interest rates are as low as they have been in this period, and the Federal Open Markets Committee (FOMC) has stated its intent to keep them close to zero for the foreseeable future. ${ }^{1}$

\footnotetext{
${ }^{1}$ The operating procedures for the discount window changed in January of 2003, so there isn't a consistent series for the discount rate for the whole time. For the federal funds rate in 2009, I plot the upper range targeted by the Federal Reserve.
} 
Figure 2 illustrates the second set of policies, which I label quantitative policy, and that reflect changes in the size of the balance sheet of the Federal Reserve and in the composition of its liabilities. In the figure are the ratio of adjusted reserves held by banks at the Federal Reserve system to annual nominal GDP since 1929, and the ratio of the monetary base (currency plus reserves) to GDP. In September of 2009, adjusted reserves were equal to $6.8 \%$ of GDP, a value only exceeded in the history of the Federal Reserve System during the seven months between June and December of 1940. The monetary base is as high relative to GDP as it has ever been in the last 50 years. $^{2}$

The third set of policies, which I label credit policy, consists of managing the asset side of the Federal Reserve balance sheet. To gauge the radical change in the investments of the Federal Reserve, figure 3 plots the ratio of U.S. Treasury bills held as a fraction of total assets, and the same ratio for total U.S. Treasury securities. ${ }^{3}$ From a status quo where the Federal Reserve held almost only U.S. Treasury securities, in the last two years it has switched into holding many other assets and more recently into securities with longer maturity.

I start my assessment with this last group of policies, because they are the least understood in theory. Using a new model of capital markets, I investigate the effects of the Federal Reserve's different investments on the availability of credit. ${ }^{4}$ In the model, entrepreneurs, lenders, traders and investors all have funds that must be reallocated through the financial system towards investment and production, but frictions may lead to credit shortages in different points of the system. Different credit programs have different effects depending on whether they tighten or loosen the several credit constraints and depending as well on the equilibrium interactions between different markets. While the Federal Reserve's credit policies have been directed at many markets and institutions, the model suggests that making senior secured loans to traders in securities markets is the most effective way to fight the crisis.

\footnotetext{
${ }^{2}$ The data are the monthly monetary base and adjusted reserves computed by the FRB of St. Louis, and nominal annual GDP from the Bureau of Economic Analysis.

${ }^{3}$ U.S. Treasury bills are 3-month securities, whereas total securities include also longer-duration bonds and notes. The figure includes only the securities held outright, not those held as part of repurchase agreements.

${ }^{4}$ The model is a simple version of the more complete analysis in Reis (2009).
} 
Next, I move to quantitative policy, and ask the question: does the increase in the size of reserves and the central bank's balance sheet undermine the current policy regime of controlling inflation? I show that, according to a standard model of price-level determination, this is only the case if the Federal Reserve becomes excessively concerned with the state of its balance sheet, or if it gives in to pressure from the fiscal authorities, effectively surrendering its independence.

Finally, I turn to interest-rate policy. I briefly survey the literature on optimal monetary policy in a liquidity trap, which recommends committing to higher than normal inflation in the future, and keeping interest rates at zero even after the negative real shocks are gone. The Federal Reserve's actions fit into these directions qualitatively, although they seem too modest relative to the theoretical prescriptions.

The last section concludes.

\section{What has the Federal Reserve been up to?}

There are already a few description of the events in the U.S. financial crisis of 2007-09. ${ }^{5}$ After a brief and selective summary, the goal of this section is to catalog the policies followed by the Federal Reserve in response to these events.

\subsection{The financial and real crisis}

In August of 2007, an increase in delinquencies in subprime mortgages led to a sharp fall in the price of AAA-rated mortgage-backed securities together with suspicions about the actual value of their backing. Because many banks held these securities, either directly or through special investment vehicles, there were doubts over the state of bank's balance sheets. Through 2007, there were fears that many banks may fail, and interbank lending rates spiked to levels well above those in the Federal Funds market. This increase in risk spreads diffused over many markets, and in a few of them, notably the markets for commercial paper, private asset-backed securities (ABS), and collateralized debt obligations (CDO), the decline in volume traded was extreme, apparently due to lack of demand.

\footnotetext{
${ }^{5}$ See Brunnermeier (2009), Gorton (2009) and Greenlaw et al. (2008).
} 
In the real economy, the U.S. business cycle peaked in December of 2007, according to the NBER. Unemployment has since been steadily rising from an initial $4.9 \%$ to a current (in September 2009) value of $9.8 \%$, and measures of output have also been on the decline. The net acquisition of financial assets by households fell from $\$ 1,404$ billion in 2007 , to $\$ 728$ billions in 2008 , to $-\$ 281$ billion so far in 2009 , although as of the start of 2008 , there was still no sharp fall in total bank lending.

Returning to financial events, in March 2008, the investment bank Bear Stearns was on the verge of bankruptcy, unable to roll over its short-term financing. The government, in a joint effort by the Federal Reserve and the Treasury, stepped in and arranged for a sale of Bear Stearns to JP Morgan Chase, providing government guarantees on some of the assets. Risk spreads remained high and the ABS market was effectively closed for the rest of the year, but some calm was returning to markets until the dark week of September 15 to 21 arrived.

The extent of the crash during these seven days probably only finds a rival in the stock market crash of October 1929. It was marked by three distinct events. The first event was the bankruptcy of Lehman Brothers on September $15^{\text {th }}$, the largest ever company to fail in U.S. history. This investment bank was a counterparty in many financial transactions through several markets, triggering defaults on contracts all over the world. The second event was the bailout of American International Group (AIG), one of the largest insurance companies in the world, on the evening of September $16^{\text {th }}$. The bailout not only signaled that financial losses went well beyond investment banks, but it also increased the uncertainty on what would be the government response to future cases. Finally, the third event, on September $20^{\text {th }}$, was the announcement of the first version of the Troubled Asset Relief Program, or TARP (also known as the "Paulson plan"), which was short, vague, and potentially far-reaching.

In the six months that followed, the stock market plunged, with the Standard \& Poor's 500 index falling over $56 \%$ between its peak in October 2007 and its trough in March of 2009. Most measures of volatility, risk and liquidity spreads increased to unprecedented levels, and measures of real activity around the world declined. Which of the three events was the main culprit for the financial crisis that followed is a question that will surely 
motivate much discussion and research in the years to come. ${ }^{6}$

The Treasury has throughout these events cooperated with the Federal Reserve, and it has pursued its own policies in response to the crisis. Today, these include a plan to invest up to $\$ 250$ billion in the capital of banks, offering assistance to homeowners unable to pay their mortgages, and using up to $\$ 100$ billion of the TARP money in public private investments to buy legacy securities and loans. Since March 2009, some stability has returned to financial markets, with measures of risk spreads shrinking and the stock market partly recovering. Forecasts of unemployment and output show yet no clear signs of improvement.

Finally, inflation measured using year-on-year changes in the Consumer Price Index has fallen from $4.2 \%$ in December 2007 to $-1.3 \%$ in September of 2009. Inflation forecasts for the coming year, according to the median answer in the Survey of Professional Forecasters, have fallen from $3.6 \%$ in the last quarter of 2007 to $0.7 \%$ in the third quarter of 2009 , while the forecast for average inflation over the next 10 years has slightly risen from $2.4 \%$ to $2.5 \%$.

\subsection{The Federal Reserve's actions during the crisis}

Typically, the Federal Reserve uses a very narrow set of actions in the conduct of monetary policy. It intervenes in the Federal Funds market, where many banks make overnight loans, by making open-market operations with a handful of primary dealers. These are collateralized purchases and sales of Treasury securities, crediting or debiting the banks' holdings of reserves at the central bank. The Federal Reserve announces a desired target for the equilibrium interest rate in the Federal Funds market, and ensures that the market clears close to this rate every day.

Over the course of the last two years, this has changed dramatically. Table 1 gives a snapshot of the actions of the Federal Reserve at three points in time: in January 2007 before the start of the crisis (and representative of the decade before), two years later in the midst of the crisis in January 2009, and more recently in July of 2009. The Federal Reserve's policies fit into three broad categories. ${ }^{7}$

\footnotetext{
${ }^{6}$ The situation at the time looked so dire that the head of the International Monetary Fund, Dominique Strauss-Kahn on October 12th stated apocalyptically: "Intensifying solvency concerns about a number of the largest US-based and European financial institutions have pushed the global financial system to the brink of systemic meltdown."

${ }^{7}$ For alternative descriptions of the policy responses to the crisis, see Cecchetti (2009) for the United
} 
The first group is interest-rate policy. Starting from a target for the Federal Funds rate of $5.25 \%$ for the first half of 2007 , the Federal Reserve has gradually reduced it to effectively zero by December of 2008. ${ }^{8}$ In its policy announcements, the Federal Reserve has made clear that it expects to keep the rate at zero for an extended period of time. ${ }^{9}$ Starting in October 2008, the Federal Reserve has also been paying interest on both required and excess reserves held by commercial banks and, since December of 2008, the interest on reserves has been the same as the Federal Funds rate target. This implies that there is no longer a tax on banks in keeping reserves at the central bank beyond the legal requirements. It also means that the Federal Reserve in the future has at its disposal a new policy instrument, the spread between that rate and the interest on reserves. ${ }^{10}$ Finally, the Federal Reserve has purchased other securities with a stated intent of affecting their prices and yields, although there is little evidence that it has been successful at doing so. ${ }^{11}$

The second group I label quantitative policy, and it concerns the size of the Federal Reserve's balance sheet and the composition of its liabilities. Historically, the bulk of the liabilities of the Federal Reserve have consisted of currency in circulation plus bank reserves (most of which required by law) and deposits from the Treasury and foreign central banks. With the crisis, the first change is that the Federal Reserve's balance sheet more than doubled. Reserves have accounted for much this increase and they are now mostly voluntary, since the penalty in holding reserves instead of lending in the federal funds market has effectively disappeared once the rates on both became the same. The final significant change in quantitative policy is that the main individual creditor of the Federal Reserve

States, and Blanchard (2009) for the international side, as well as the many speeches from governors of the Federal Reserve at http://www.federalreserve.gov/newsevents/default.htm. An up-to-date exposition is provided by the Federal Reserve at http://www.federalreserve.gov/monetarypolicy/bst.htm

${ }^{8}$ To be more precise, since December 2008 the Federal Reserve started announcing upper and lower limits for this rate of $0.25 \%$ and $0 \%$, respectively.

${ }^{9}$ The December 2008 press release of the Federal Open Markets Commitee (FOMC) stated that "...the Committee anticipates that weak economic conditions are likely to warrant exceptionally low levels of the federal funds rate for some time." The commitment to low interest rates has been reaffirmed at every meeting since then, with slightly different words since March of 2009.

${ }^{10}$ The Federal Reserve also controls the interest rate that it charges banks that borrow from it directly at the discount window, and while banks rarely use the discount window during normal times, this facility can be important during crises.

${ }^{11}$ For instance, in April of 2009, vice-chairman Donald Kohn wrote "...the Federal Reserve has begun making substantial purchases of longer-term securities in order to support market functioning and reduce interest rates in the mortgage and private credit markets." Chairman Bernanke stated that "The principal goal of these programs is to lower the cost and improve the availability of credit for households and businesses." 
became the U.S. Treasury. As a means to provide the Federal Reserve with Treasury securities to finance its lending programs, the Treasury has greatly expanded the amount in its account, and in August of 2009 held more than one tenth of the Federal Reserve's total liabilities.

The third group of policies is credit policy. This consist of managing the composition of the asset side of the Federal Reserve's balance sheet. At the start, and similar to how it had always been since its founding, the assets of the Federal Reserve were mostly U.S. Treasury securities, with a little over one third in Treasury bills, and the remaining two thirds in notes and bonds. It also had a few foreign reserves, other assets (e.g., gold) and almost no direct loans. At the height of the crisis, in January of 2009, this picture had changed dramatically, with several new asset-purchasing programs announced. ${ }^{12}$ Going down over the items on the balance sheet, first the Federal Reserve significantly shifted the maturity of its Treasury securities from short to long-term assets. Second, the Federal Reserve for the first time made direct loans to entities other than banks, to primary dealers through the 28-day TSLF and the overnight PDCF, and to investors posting as collateral AAA-rated asset-backed securities on student loans, auto loans, credit card loans, and small business administration loans through TALF. ${ }^{13}$ Third, the Federal Reserve entered a swap agreement with foreign central banks to temporarily provide them with dollars against foreign currency, increasing the amount of foreign reserves on its balance sheet by a factor of almost 30. Fourth, through the TAF, the Federal Reserve started lending to banks for terms of 28 and 84 days against collateral at terms determined in an auction. These provided a means to lend to banks that kept the recipients anonymity in order to prevent these loans from being seen by the market as a signal of trouble by the debtor bank. In January of 2009 these credits over banks accounted for more than one quarter of the Federal Reserve's assets. Fifth, the Federal Reserve bought 90-day commercial paper through the

\footnotetext{
${ }^{12}$ The initials of different programs are: TAF for the Term Auction Facility, TSLF for the Term Securities Lending Facility, PDCF for the Primary Dealer Credit Facility, CPFF for Commercial Paper Funding Facility, TALF for Term Asset-Backed Securities Loan Facility, AMLF for Asset-Backed Commercial Paper Money Market Mutual Fund Liquidity Facility, and MMIFF for Money Market Investor Funding Facility.

${ }^{13}$ The Federal Reserve also made funds available to lend to the money market, through the MMIFF for money-market funds, and through the AMLF programs for banks to finance purchases from money-market funds. The first program was never used, while the funds under the AMLF are included in the "Direct Loans" section of the balance sheet, but have currently a balance of zero.
} 
$\mathrm{CPFF}$, therefore financing many companies directly without going through banks. Sixth, it created three limited liability companies, Maiden Lane LLC, to acquire and manage the assets associated with the bail-outs of AIG and Bear Stearns.

By today, some of these programs have reduced significantly, in particular the holdings of commercial paper and foreign reserves, as can be seen on panel $\mathrm{C}$ of table 1 . Others though are growing further. In particular, in March 2009, the Federal Reserve announced it would further boost this trend, by purchasing up to $\$ 300$ billion of long-term Treasury bonds, and $\$ 1,450$ billion of agency debt and mortgage-backed securities and it expects to reach these goals by the end of the first quarter of 2010. A large share of the plan is already reflected in its August balance sheet. ${ }^{14}$

\section{A credit-frictions model of capital markets}

The crisis of 2007-09 has had credit disruptions involving multiple agents in many markets, it has had large swings in asset-backed securities, and it has propagated from financial markets to the real economy. Unfortunately, there is no off-the-shelf model that contains all of these ingredients. Before moving to interpreting the Federal Reserve's policies, I must therefore take a detour to introduce a new model that captures them.

Financial markets perform many roles, including the management of risk and the transformation of maturity. In the model, I abstract from these better understood roles to focus on another role of financial markets: the re-allocation of funds towards productive uses. I take as given a starting distribution of funds across agents, and study how trade in financial markets shifts these funds to where they are needed, subject to limits due to asymmetries of information. The model merges insights from the theory of bank contracts based on limited pledgeability (Holmstrom and Tirole (2009)) with the theory of leverage based on collateral constraints (Kiyotaki and Moore (1997), Matsuyama (2007)). It is a simpler version of a model fully developed in Reis (2009). The appendix lays out the model in more detail.

\footnotetext{
${ }^{14}$ These changes were announced at the FOMC meeting of March 2009, but they had been under discussion for a few months before.
} 


\subsection{Setup of the model: the agents}

There are three periods, no aggregate uncertainty, and a representative consumer-worker. She supplies labor in all three periods, earning a wage $W$ in each period, and consumes a final good $C^{\prime \prime}$ in the last period, which is a Dixit-Stiglitz aggregator of a continuum of varieties. There is only one storable asset in this economy, in amount $H$, which I will refer to as capital. It consists of claims issued by the government, which can be redeemed for the consumption good in the final period. The government levies a lump-sum tax on the representative household in the last period to honor these claims. ${ }^{15}$

The representative household has four different types of financial agents, each endowed with an initial allocation of capital. First, there are many investors behaving competitively, with capital $M$.

The second type of agents are entrepreneurs. There is a continuum of them in the unit interval associated with each variety of the good. In the first period, they must hire $F$ units of labor to set up operations. Further labor is then hired in the second and third periods, to produce monopolistically in the last period a variety of consumption goods in amount $Y_{i}^{\prime \prime}$. The production function is:

$$
Y_{i}^{\prime \prime}=A_{i}^{\prime} \min \left\{\frac{L_{i}^{\prime}}{v}, \frac{L_{i}^{\prime \prime}}{1-v}\right\}
$$

At the optimal choice of labor in the second and third period, $v$ will be the fraction of labor employed in the second period. Exogenous productivity, $A_{i}^{\prime}$ is i.i.d. across the continuum of firms, and is revealed in the second period, before the labor decision is made. With probability $1-\phi$, it equals $a$, while with probability $\phi$ it is zero. Therefore, if $I \in[0,1]$

\footnotetext{
${ }^{15} \mathrm{~A}$ few notes are in order regarding this capital. First, it is a very crude way to introduce an asset in this economy that is used as a means of payment. However, it allows me to keep the focus on the credit frictions, and not on the underlying theory of money or assets. Second while I assume that, like money, capital gives a zero net return, generalizing the model to a positive return does not change the results qualitatively. Third, I use the term capital and not money because these assets can be thought of as more broadly than just high-powered money. They are any claims that can be exchanged for consumption goods in the last period, so they refer to all assets in this economy. Fourth, note that these could be private claims issued by the representative consumer, if it could commit to their payment, dispensing with the need for a government or taxes. However, decentralizing this economy to justify the existence of the representative consumer is a difficult task. Fifth, an alternative would be to assume that $H$ is a physical good that can be stored without depreciating and can be transformed into the final consumption good in the final period. This leads to similar predictions to the model in this paper, but messier algebra.
} 
projects are funded in the first period, only $N=(1-\phi) I$ yield positive output in the last period.

This production structure captures the maturing process of investments, with expenses in every period to finally get a payoff in the last period, together with the risk that set-up costs may not be recouped if the technology turns out to be worthless. The entrepreneurial capital available is $K$, which is smaller than $W F$, so that entrepreneurs must seek outside financing.

The third type of agents are lenders. Their distinguishing feature is that they are the only ones with the ability to monitor the behavior of entrepreneurs. If investors were to finance entrepreneurs directly, they could not prevent them from running away with all of the funds. Lenders, instead, can prevent the entrepreneur from absconding with no more than a share $\delta$ of the sales revenues. Entrepreneurs can therefore pledge $1-\delta$ of the revenues to lenders and 0 to all others. ${ }^{16}$ I assume that the pledgeable revenues are enough to ensure positive pledgeable profits to lenders. A lender will provide the needed capital to start the project, $W F-K$, as well as a line of credit in the second period to pay for the wages $W L^{\prime}$.

To fund these investments, lenders have capital $D$ in the first period, and possibly a new infusion $D^{\prime}$ in the second period. If they require further financing, they can issue and sell asset-backed securities, guaranteed by the loans they make, in total amount $S$ for price $Q$ in the first period, and $S^{\prime}$ and $Q^{\prime}$ in the second period. ${ }^{17}$ These securities pay one unit of capital in the last period, as long as the project is in operation. In the data, lenders include all the providers of financing to the non-financial sectors, including commercial banks, primary issuers of commercial debt, some brokers, etc.

The fourth and final group of agents are traders. While they cannot monitor loans, together with lenders, they have the unique ability to understand and trade the securities. In particular, in the first period, lenders could try to sell as many securities as they wanted

\footnotetext{
${ }^{16}$ This limited pledgeability constraint has a long tradition in the modelling of capital market imperfections: see Matsuyama (2007) and Holmstrom and Tirole (2009) for recent reviews. Note that one can re-interpret the $F$ set-up costs as being the cost for lenders to set up the monitoring technology that only they have access to allowing to seize $\delta$ of the revenues.

${ }^{17}$ Note that $S$ is the total revenue from selling the security in the first period, so $S / Q$ is the number of securities sold paying this amount of capital in the third period. The same applies to $S^{\prime}$.
} 
whether they had proper backing or not. Traders are the only ones that can verify that there is proper backing for a recently issued security. Traders also observe the realization of productivity in the second period, while investors do not. They therefore perform the role of intermediating the access of investors to the securities. In the United States, traders include investment banks, hedge funds, special investment vehicles set up by commercial banks, and many others.

Traders have capital $E$ in the first period, and an extra $E^{\prime}$ available in the second period. They can obtain extra funds from investors, but I assume there is another friction preventing investors from effectively owning the traders and acquiring access to their information technology. I again use a pledgeability constraint, assuming that investors can only seize a share $1-\mu$ of the assets of a trader, so this is the maximum amount of liabilities the trader can have. ${ }^{18}$ Therefore, in the first period, the total assets of the trader are $E / \mu$, where $\mu$ gives the inverse of the leverage multiplier. In the second period, because traders enter with assets equal to the securities $S$, and these are marked-to-market, their entering equity is $E+\left[(1-\phi) Q^{\prime}-Q\right] S / Q$ reflecting the capital gain (or loss) made on these investments. Because the trader can get new loans against this marked-to-market equity position, they can invest a further $[(1-\mu) / \mu]\left[(1-\phi) Q^{\prime} / Q-1\right] S$ in the second period. This ability to use capital gains to boost leverage is also emphasized in Krishnamurthy (forthcoming) and Shleifer and Vishny (2009). ${ }^{19}$

\subsection{Setup of the model: financial markets}

Having presented the agents, I now describe the markets in which they interact at each date. In the first period, entrepreneurs need financing to set up their firms. Because of the need for monitoring, only lenders are willing to provide them with capital. Lenders behave competitively in funding each project, but once a lender is matched with an entrepreneur, they stay together until the last period. If lenders do not have enough capital, they can issue securities, that only traders will choose to buy since only they can ensure that the securities

\footnotetext{
${ }^{18}$ If traders abscond with the securities, I assume that they can show up to redeem their payment in the last period.

${ }^{19}$ Lenders cannot obtain direct financing from investors, since in equilibrium their assets will consist solely of the outstanding loans. Only lenders can monitor these loans, so seizing the lenders' assets leads to zero revenue. Therefore, investors are not willing to give capital directly to lenders.
} 
are legitimate. Investors deposit funds in traders. I assume that $K+D+E<W F$, so that everyone's funds, including investors, is required to set up all the projects.

In the second period, entrepreneurs require more capital and obtain it from their line of credit with their lender. The lender may issue more securities, and traders can again choose to buy them. At this time though, investors can also buy the pre-existing securities, because lenders and traders have signaled they are backed by loans by trading them in the first period. However, investors cannot distinguish securities backed by assets with $A_{i}^{\prime}=a$ from those with $A_{i}^{\prime}=0$. Therefore, as long as $Q^{\prime}>1-\phi$, they will stay out of buying securities directly in this market. Lenders and traders, on the other hand, can distinguish between the two types of securities, so if investors stay out, the price of the $A_{i}^{\prime}=0$ securities is zero, and $Q^{\prime}$ refers to the price of the $A_{i}^{\prime}=a$ securities.

Finally, in the third period, the entrepreneur obtains the revenue from sales, pays the last-period workers and pays back the loan to lenders. They use part of the funds to repay the holders of securities backed by the loans, while traders repay their loans to investors. In the end, they all return their capital to the representative household. All of these financial market participants are risk-neutral and aim to maximize their last-period payoff.

Figure 4 summarizes the timing and the flows of funds just described. I assume that there is enough liquidity to sustain the social optimum, where all projects get funded and marginal costs just depend on wages and productivity, which is equivalent to assuming that total capital $H$ is higher than the setup and up-front labor costs at the efficient level. The problem I focus here is on the allocation of this liquidity, in the presence of the frictions captured by the three parameters, $\delta, \phi$, and $\mu$.

\subsection{Closing the model}

To close the model, I need a few more ingredients, spelled out in more detail in the appendix. The first is the demand for each variety, which is iso-elastic: $Y_{i}^{\prime \prime}=C^{\prime \prime} P_{i}^{\prime \prime m /(1-m)}$, where $C^{\prime \prime}$ is total final consumption, and $P_{i}^{\prime \prime}$ is the price of the good. The lender and entrepreneur jointly decide the optimal scale of production for the productive firms in periods two and 
three to maximize joint returns:

$$
\max _{P_{i}^{\prime \prime}, Y_{i}^{\prime \prime}, L_{i}^{\prime}, L_{i}^{\prime \prime}}\left\{P_{i}^{\prime \prime} Y_{i}^{\prime \prime}-W L_{i}^{\prime \prime}-W L_{i}^{\prime} / Q^{\prime}\right\}
$$

subject to the production function in equation (1) and the demand for the good. The optimality condition is:

$$
P_{i}^{\prime \prime}=m\left(1-v+\frac{v}{Q^{\prime}}\right)\left(\frac{W}{a}\right)
$$

together with $L^{\prime}=v\left(L^{\prime}+L^{\prime \prime}\right)$. I assume that $m \in[1,2]$, so that markups are between 0 and 100 percent, and that $(1-\delta) m>1$, so that the pledgeable profits to lenders are positive.

In a symmetric equilibrium, the production of all firms is the same $Y$. Total consumption then is $C=N^{m} Y$, which is increasing with the number of goods produced because of a love for variety. Moreover, all prices are the same in equilibrium, which since consumption goods and capital have the same price, implies that $N^{1-m} P_{i}^{\prime \prime}=1$, so the static cost-of-living price index is constant. Finally, the labor supply function is $C^{\prime \prime}=W$, which follows from assuming log preferences over consumption and linear disutility of labor supply.

Combining all of these equations provides the solution for the following endogenous variables: wages, total employment in the second and third periods, and the pledgeable amount of operating profits:

$$
\begin{aligned}
L^{\prime}+L^{\prime \prime} & =\frac{1}{m\left(1-v+v / Q^{\prime}\right)(1-\phi) I} \\
W & =\frac{a[(1-\phi) I]^{m-1}}{m\left(1-v+v / Q^{\prime}\right)} \\
\pi_{i}\left(Q^{\prime}, I\right) & \equiv(1-\delta) P_{i}^{\prime \prime} Y_{i}^{\prime \prime}-W L_{i}^{\prime \prime}-W L_{i}^{\prime} / Q^{\prime} \\
& =\frac{[(1-\delta) m-1] a}{m^{2}\left(1-v+v / Q^{\prime}\right)[(1-\phi) I]^{2-m}}
\end{aligned}
$$

\subsection{The financial equilibrium}

There are two restrictions on prices that come from no-arbitrage. First, since a security bought in the first period for price $Q$ will, with probability $1-\phi$, be worth $Q^{\prime}$ in the second period, but 0 otherwise, and since lenders can sell it in the first period and buy it back in the second period, it must be that $Q \leq(1-\phi) Q^{\prime}$. Otherwise, lenders would make 
infinite expected profits. ${ }^{20}$ Second, and similarly, because lenders can hold cash between the second and third periods with a guaranteed return of 1 , it must be that $Q^{\prime} \leq 1$.

I now characterize the equilibrium securities price and investment in the first period. In the securities market in the first period, if $Q<(1-\phi) Q^{\prime}$, traders strictly prefer to buy securities rather than hold cash so their total demand is $E / \mu$. If $Q=(1-\phi) Q^{\prime}$, they are indifferent between cash or securities, so they will be willing to buy any amount of securities below $E / \mu$. Turning to the supply of securities, if $Q<(1-\phi) Q^{\prime}$, it equals the total investment minus the capital of the entrepreneurs and lenders: $W F I-K-D$. If $Q=(1-\phi) Q^{\prime}$, the lender is indifferent between issuing this amount of securities or any higher amount. Equating demand and supply for $Q<(1-\phi) Q^{\prime}$, and replacing for equilibrium wages from equation (5), gives the first-period securities-market equilibrium condition $(S M)$ :

$$
I^{m}=\left(K+D+\frac{E}{\mu}\right)\left[\frac{m}{a(1-\phi)^{m-1} F}\right]\left(1-v+\frac{v}{Q^{\prime}}\right) .
$$

In $(I, Q)$ space this defines a vertical line for $Q$ between 0 and $(1-\phi) Q^{\prime}$.

The expected profits of lenders in the first period are $Q(1-\phi) I \pi\left(Q^{\prime}, I\right)-W F I+K$. There is free entry into this sector, so lenders will enter as long as there are available projects, and profits are strictly positive. If $Q$ is above a certain level $Q^{*}$, then $I=1$, and lenders earn positive rents in exchange for their monitoring services. ${ }^{21}$ If $Q \leq Q^{*}$, then lenders' profits are driven to zero so $Q(1-\phi) I \pi\left(Q^{\prime}, I\right)-F W I+K=0$. Solving this equation for $I$, and replacing for pledgeable profits from equation (6) gives:

$$
a(1-\phi)^{m-1} I^{m}\left(F-\frac{Q[(1-\delta) m-1]}{m I}\right)=K m\left(1-v+\frac{v}{Q^{\prime}}\right)
$$

This is the zero-profits equilibrium condition $(Z P)$, when $Q \leq Q^{*}$ and investment is below

\footnotetext{
${ }^{20}$ The fact that capital gains on holding a portfolio of securities are always non-negative is a consequence of the lack of aggregate uncertainty. It is straightforward to extend the model to have uncertainty; since all agents are risk-neutral, this would change little in the analysis after replacing expected for actual values.

${ }^{21} Q^{*}$ is defined as:

$$
Q^{*}=\frac{W F-K}{(1-\phi) \pi\left(Q^{\prime}, 1\right)}
$$
}


one. It defines investment implicitly as an increasing function of $Q$. Intuitively, as the price of securities increases, financing is cheaper, so the amount of entrepreneurial capital needed per project falls and more projects are funded.

Turning to the securities market in the second period, if $1-\phi<Q^{\prime}<1$, the demand comes solely from traders and equals:

$$
S^{\prime}=\frac{E^{\prime}}{\mu}+\left(\frac{1-\mu}{\mu}\right)\left[\frac{(1-\phi) Q^{\prime}}{Q}-1\right]\left(\frac{E}{\mu}\right) .
$$

The first term is the demand from the new capital and the second term is the extra demand form leveraging capital gains. If $Q^{\prime}=1$, the trader is indifferent between zero and the amount in equation (9). As $Q^{\prime}$ falls, the expected capital gain for traders is smaller and so they have fewer funds to demand securities. If $Q^{\prime}$ falls all the way to $1-\phi$, then investors start buying securities directly satisfying the supply at that price.

The supply of securities comes from lenders who need capital to cover their outstanding credit lines, so it equals $(1-\phi) I W L^{\prime}-D^{\prime}$ if $Q^{\prime}<1$. Replacing for the equilibrium labor and wage from equations (4)-(5) gives the supply function for securities in the second period:

$$
S^{\prime}=\frac{v a(1-\phi)^{m-1} I^{m-1}}{m^{2}\left(1-v+v / Q^{\prime}\right)^{2}}-D^{\prime}
$$

This is increasing in $Q^{\prime}$ since a higher price of securities implies a lower marginal cost of production and therefore an increase in the scale of each firm. This requires more funds to finance operations, so higher credit lines, and more securities issued. When $Q^{\prime}=1$, the lenders become indifferent between supplying this and any higher amount.

Conditions (7)-(10), provide four conditions to determine the four endogenous variables: the equilibrium price of securities in the first and second period $\left(Q\right.$ and $\left.Q^{\prime}\right)$, the amount of investment in the first period $(I)$, and the scale of operations and funding in the second period $\left(S^{\prime}\right)$. Together they define the equilibrium in this economy. ${ }^{22}$ There are three possible equilibria that I describe next.

\footnotetext{
${ }^{22}$ With these four variables, then equilibrium wages and hours worked are determined by equations (4) and (5). Equilibrium output and consumption follow from using the production function and the market-clearing condition in the goods' market.
} 


\subsection{The equilibrium}

The first case is the efficient economy where, in spite of the financial frictions, still all projects are funded $I=1$ and financing does not add to the marginal cost of firms: $Q^{\prime}=1$. One can show that this this will be the case if $\delta, \mu$, and $\phi$ are each below some threshold. Intuitively, if $\delta$ is not too high, then the lenders are able to appropriate enough of the entrepreneurs' revenues, so their profits are high enough and they wish to finance all the projects. If $\mu$ is low enough, the friction impeding the flow of funds from investors to traders is not too severe, so their funds can satiate the market for securities. Finally, if $\phi$ is low enough, the expected profits of lenders at date 1 are high inducing full investment, and investors put a high lower bound on the price of securities in the second period.

The second case is the other extreme, of a catastrophic economy, where the price of securities in the second period has fallen to $1-\phi$. Investors start buying securities directly, but because they cannot distinguish profitable from unprofitable assets, for each dollar they spend on a a worthwhile security, $\phi /(1-\phi)$ dollars buy a worthless security, squandering funds and destroying resources. This low price of securities implies that the marginal cost of production $\left(1-v+v / Q^{\prime}\right)$ is high so that each firm will be operated at a low inefficient scale. And as $Q$ is even lower, below $(1-\phi)^{2}$, the cost of financing to set up projects in the first period is very high and few firms are set up in the first place.

In between these two extremes is the constrained economy. Figure 5 plots this case. In the top panel, the equilibrium price of securities and investment in the first period are determined, taking as given the price of securities in the second period. The vertical line is the $S M$ condition in equation (7), while the upward-sloping curve is the $Z P$ condition in equation (8). The bottom panel has the equilibrium price in the second period and the scale of the projects, taking as given the price and investment from the previous period. The line depicts the demand function in equation (9), while the curve is the supply function in equation (10). In this economy, there is an extensive-margin inefficiency as $I<1$. Traders do not have enough assets, either because of low capital or tight leverage constraints from investors, so the price of securities $Q$ is below $Q^{*}$, making the up-front cost of investing too high relative to the future revenues. There is also an intensive-margin inefficiency since $Q^{\prime}<1$ so the marginal costs of production exceed $W / a$. Operating firms will hire too little 
labor and produce too little output, because there isn't enough second-period capital in the hands of traders to satisfy the residual need for funds by lenders. ${ }^{23}$

Intuitively, for the economy to be operate efficiently, investors' capital must reach entrepreneurs via traders and lenders and through the securities market. In the efficient economy, this happens as entrepreneurs have all the capital they need to set up and operate projects. In the constrained economy, leverage constraints on traders are too tight, so there are insufficient funds in the securities markets in both periods, and the pledgeability constraint and technological risk prevent lenders' capital from being enough. In the catastrophic economy, investors enter the securities market directly, but do so at great waste since they are unable to pick securities. There is severe mis-pricing and mis-allocation of capital, as worthless and worthwhile investments face the same marginal cost of capital in an inefficient pooling equilibrium. ${ }^{24}$

To understand better the role of each of the three frictions in the model, consider what happens in equilibrium as each is shut down. First, if all projects are productive $(\phi=0)$ then there is no lemons problem in the securities market. This implies that the knowledge of traders in picking securities is no longer valuable, and investors can buy securities directly from lenders. Since there is no limit to the amount of securities lenders can issue and since investors have all the necessary capital to fund all projects and run them efficiently, the only equilibrium is the efficient one. Second, assume that traders can no longer run away with capital without being detected $(\mu=0)$. In this case, investors are willing to invest all their funds with traders, who in turn will buy all the securities issued by lenders. Again, the unique equilibrium is the efficient case. Finally, if the banks have a perfect monitoring technology, they can reap all of the revenue from projects $(\delta=0)$. Lenders will be very willing to lend, reflected in figure 5 by $Q^{*}$ being quite low, making it more likely that the efficient equilibrium obtains. It is still possible though that the friction in the leveraging of traders is so strong that they cannot draw from investors even the small amount of funds

\footnotetext{
${ }^{23}$ One can see the efficient equilibrium in this graph, as it would occur where the $S M$ line was to the right of $I=1$ and in the second period, demand and supply coincided for a line segment at their top horizontal parts. The catastrophic equilibrium occurs when the supply curve intersects the demand curve in its lower horizontal segment.

${ }^{24}$ One feature of this model, as well as of most models of credit frictions, is that there is too little borrowing. Some have argued that the current crisis is due to too much borrowing instead but, to my knowledge, this has not yet been formalized.
} 
required to fund all projects, and so the constrained equilibrium persists if the $S M$ line is to the left of $I=1$.

\section{Interpreting the Federal Reserve's actions: credit policy}

In terms of the model just described, the financial events and crisis described in section 2.1 can be interpreted as a combination of two effects. First, the downgrading of many securities, following revisions downward of the underlying value of the assets backing them, can be interpreted as an increase in $\phi$ in the model. Second, the withdrawal of funds from the financial sector, and the fears about the solvency of many financial institutions, can be interpreted as an increase in $\mu$. Both of these changes can be interpreted as technological changes, or instead as changes in beliefs of the quality of assets. The economy in 2007-09 moves to a constrained equilibrium like the one depicted in figure 5 , or perhaps even on the way to the catastrophic equilibrium described in the previous section.

A policymaker would like to intervene to correct this serious misallocation of funds. Credit policy in this economy consists of transferring the capital trapped in investors hands to other agents, or alternatively issuing more claims on final output (and correspondingly taxing more consumption in the final period). What the central bank can achieve with these actions depends on what is assumed about its knowledge and skills.

One extreme is the case where the central bank has no special powers beyond those available to private investors. In terms of the model, this translates into the central bank not having the ability to monitor loans, not having the know-how to pick securities, and not having the power to be able to seize more than a share of the traders' assets. In this case, any injection of credit by the central bank in the market is equivalent to an increase in the capital of investors $M$. This does not affect any of the equilibrium conditions in the model, since the problem to be solved is not the lack of funds, but their mis-allocation. Worse, if the central bank misguidedly tries to pick securities, invest in traders, or make loans directly to entrepreneurs, its sub-optimal behavior will lead to possibly heavy losses according to the model, as money is absconded and investments turn in losses.

At the other extreme, consider the case where the central bank can become a lender, 
being able to monitor the behavior of borrowers and ensure the funds are put to good use. Then, by lending the needed funds to entrepreneurs, the policymaker could reach the social optimum, with no intervention form financial firms. This seems unrealistic, and it has absurd predictions: if the central bank could make loans as effectively as anyone else, then why have a financial system at all?

Three intermediate cases are both more interesting and more realistic.

\subsection{The central bank as a senior secure investor}

In this case, I assume that the central bank has the ability to make loans to financial institutions that will surely be fully paid. In the model, this maps into the policymaker being able to distinguish good projects and having some monitoring technology that ensures that lenders pay the central bank from the revenue of projects before they or the securities holders get paid. In reality this might be achieved by imposing that central bank loans are senior to other creditors, or by using its regulatory power.

In the model a transfer of funds $X$ to lenders in the first period raises their initial capital from $D$ to $D+X$, while leaving their profits unchanged as $X$ is returned in the final period. ${ }^{25}$ Figure 6 depicts the effect this has on the equilibrium. The $S M$ line in the first period shifts to the right, leading to an increase in investment and a rise in the price of securities. The extensive-margin moves closer to the efficient level. These changes in turn lead to an increase in the supply of securities in the second period, since $I$ is higher so the amount needed for the credit lines rises, as well as to a decline in demand, since the increase in $Q$ lowers expected capital gains for traders. Therefore, the price of securities in the second period unambiguously falls, raising marginal costs, and leading to a worsening of the intensive-margin. Second-round effects then follow as the lower $Q^{\prime}$ lowers expected profits of banks, shifting the zero-profit condition to the left and lowering investment, and so on. As a result of the central bank's actions, more firms are in operation, but each at a smaller inefficient scale.

In comparison, consider what happens if the loans $X$ are to traders instead, also por-

\footnotetext{
${ }^{25}$ This assumes that the Federal Reserve is not trying to make profits from the loan, so the net interest rate it charges is zero.
} 
trayed in figure 6 . Their total assets in the first period increase to $E / \mu+X$, which has exactly the same effect on the first-period equilibrium as the funds to lenders. However, in the second-period market, the increase in assets of traders implies that they will have higher capital gains. Because traders mark their equity to market, they now have an extra source of funds to demand securities in period 2, so the demand curve will be to the right of the one in the lenders case (in the figure it is drawn as unchanged form the initial case). Therefore, the price of second-period securities falls less than it did with the central bank's loan to lenders. This intervention does not have the same intensive-margin inefficiency that the loan to lenders did.

Alternatively, consider providing loans to traders or lenders in the second period. Briefly staring at the two equilibrium conditions, equations (9) and (10), and seeing that $E^{\prime} / \mu$ and $D^{\prime}$ enter symmetrically, it follows that loans to traders or lenders would have an equivalent effect. They would raise $Q^{\prime}$ and improve intensive-margin inefficiency. At the same time, they lower investment in the first period (see equation (7)) and so worsen the extensive margin. ${ }^{26}$ Note that the crucial difference between the first and second periods in the model is whether the securities are coming due next period or not. The indifference between injecting funds in traders and lenders applies only to the securities that are about to mature; for all other securities, loans to traders are more effective because they affect traders' equity and leverage in future periods.

The theory therefore suggests that providing funds to traders of new securities is more effective than doing so to lenders. The intuition is that, through capital gains, traders can use increases in equity to raise their leverage and draw more of the plentiful funds in the hands of investors to where they are scarce and needed in the securities markets. For the Federal Reserve, it is more natural to extend loans to commercial banks, as it involves little departure from its common procedures. The creation and popularity of the 90-day loans under TAF, instead of the overnight loans in the Federal Funds market, are an example of directing funds to lenders. At the same time, programs such as the TSLF, PDCF, and TALF are closer to the injection of funds into traders that the model recommends.

\footnotetext{
${ }^{26}$ Leaving the constrained equilibrium and reaching the efficient one would require large loans $X$ in either or both periods. If that is not possible, then a well-calibrated increase in the funds available to traders in both periods could simultaneously improve both extensive and intensive margin efficiency.
} 


\subsection{The central bank as a buyer of securities}

Next, consider the stricter case where the central bank has the know-how to evaluate securities in the second period, distinguishing those that are associated with profitable firms from those that are worthless. In this case, the central bank can use its funds $X$ to buy securities directly, shifting the demand curve on the right panel of figure 5 to the right. In the model, this is precisely equivalent to lending funds to traders or lenders in the second period, as was just just discussed. It is less effective than lending to traders in the first period because it does not draw into the market funds form private investors.

The Federal Reserve followed this path for most of 2008 through the CPFF program that bought commercial paper. This agrees with the model's prescriptions, since it has the same effect on the equilibrium as loans to traders, but the latter in reality are likely easier to manage and less risky. Moreover, in practice, once the central bank starts picking which securities to buy, it opens itself to political and lobbying pressures that may be dangerous.

\subsection{The central bank as an equity investor}

Through its public-private partnerships and its capital stakes in banks, the Treasury has become an equity holder in many financial firms. The Federal Reserve has not done so explicitly, although the uncomfortable actions in support of the rescue of Bear Stearns and AIG make it close to being a de facto investor. ${ }^{27}$

In terms of the model, this case differs from the previous one because the purchases of securities by the traders increase not by $X$, but rather by $X / \mu$. That is, the difference is that with an equity stake, the new funds can be leveraged up, drawing more capital from investors into the securities market. In terms of the model, this is unambiguously better than providing loans.

However, this is only a good option in the model if the central bank can prevent its

\footnotetext{
${ }^{27}$ The discomfort with these actions is clear in the 2009/04/09 speech by Ben Bernanke, regarding Maiden Lane LLC: "[The purchases covered by Maiden LLC] are very different than the other liquidity programs discussed previously and were put in place to avoid major disruptions in financial markets. From a credit perspective, these support facilities carry more risk than traditional central bank liquidity support, but we nevertheless expect to be fully repaid [...] these operations have been extremely uncomfortable for the Federal Reserve to undertake and were carried out only because no reasonable alternative was available."
} 
partners from absconding with a share $\mu$ of the assets. ${ }^{28}$ Moreover, in real life, it requires that the government behaves like a profit-maximizing shareholder in the firms. Both conditions may not be true and surely come with some risk.

\section{Interpreting the Federal Reserve's actions: quantitative policy}

The large increase in the amount of outstanding reserves and in the size of the Federal Reserve's balance sheet can cause worries. If "inflation is always and everywhere a monetary phenomenon", Milton Friedman's famous dictum, then the creation of so much money in the past two years might indicate that inflation is to come.

However, there are good reasons to be skeptical of the tight link between money and inflation that a strict monetarist stance would suggest. Empirically, the attempts at money targeting in the United States and the United Kingdom in the early 1980s were a failure, and even though Japan in the 1990s increased reserves in a similar scale to the United States, deflation persisted. Theoretically, conventional models of inflation predict that reserves are irrelevant for the setting of interest rates or the control of inflation. ${ }^{29}$ This section discusses these theoretical arguments and examines to what extent the crisis may have modified them.

\footnotetext{
${ }^{28}$ In reality, this absconding is not literal. It may involve picking dishonest partners, putting too little effort, or diverting company investments towards private gains.

${ }^{29}$ See Woodford (2008), among many others.
} 


\subsection{A simple model of price-level determination}

Consider the following model of price level $\left(P_{t}\right)$ determination with no uncertainty:

$$
\begin{aligned}
\left(1+i_{t}\right) P_{t} / P_{t+1} & =C_{t+1} / \beta C_{t} \\
M_{t} / P_{t} & =L\left(i_{t}-i_{t}^{m}, C_{t}\right) \\
P_{t} G_{t}+i_{t-1} B_{t-1} & =P_{t} T_{t}+V_{t}+B_{t}-B_{t-1} \\
B_{t} & =B_{t}^{P}+B_{t}^{F} \\
V_{t}+i_{t-1}^{m} M_{t-1}+B_{t}^{F}-B_{t-1}^{F}+K_{t}-K_{t-1} & =M_{t}-M_{t-1}+i_{t-1} B_{t-1}^{F}+q_{t-1} K_{t-1} \\
\ln \left(1+i_{t}\right) & =\chi \Delta \ln \left(P_{t}\right)+x_{t}
\end{aligned}
$$

The first equation is the Euler equation for consumption equating the real interest rate (the gross nominal rate $1+i_{t}$ divided by gross inflation $\left.P_{t+1} / P_{t}\right)$ to the discounted change in the marginal utility of consumption, which with log utility equals consumption growth. The second equation is the demand for real reserves $\left(M_{t} / P_{t}\right)$. It depends negatively on the opportunity cost of holding reserves instead of bonds, which is the difference in the interest rates paid on the two assets $\left(i_{t}-i_{t}^{m}\right)$. When this difference is zero, then holding fixed the other determinants of the demand for reserves, the private sector is indifferent between holding any amount of reserves above some satiation level. ${ }^{30}$

The following two equations refer to the behavior of the Treasury. Equation (13) is the budget constraint. On the left-hand side are resources spent on government spending $\left(G_{t}\right)$ plus the payment of interest on outstanding bonds $\left(B_{t}\right)$. On the right-hand side are the revenues, from taxes $\left(T_{t}\right)$, transfers from the Federal Reserve $\left(V_{t}\right)$, and issuances of new debt. The following equation is the market clearing condition for government debt, which may be held by the Federal Reserve $\left(B_{t}^{F}\right)$ or by private agents $\left(B_{t}^{P}\right)$.

The final two equations apply to the central bank. It spends funds in transfers to the Treasury, pays interest on reserves, and buys either government securities or private assets $\left(K_{t}\right)$. This spending is financed by issuing new reserves and by the interest collected on

\footnotetext{
${ }^{30}$ One assumption implicit in these two equations is that real money balances do not affect the marginal utility of consumption. While deviations from this strict separability can have strong theoretical implications for monetary policy (Reis (2007)), empirically the deviations seem small (see section 3.4 in Woodford (2003)).
} 
the government bonds and on the portfolio of private securities with return $q_{t}$. The last equation is the policy rule for the interest rate, with $\chi>1$, and policy choices $x_{t} .{ }^{31}$

To focus on the price level, I take consumption as exogenous, and to focus on monetary policy, government spending is also exogenous. In the model, the Federal Reserve's policy is captured by its choices of interest rates $\left\{x_{t}, i_{t}, i_{t}^{m}\right\}$, quantitative policy on the amount of reserves and transfers to the Treasury $\left\{M_{t}, V_{t}\right\}$, and credit policy on what assets to hold $\left\{B_{t}^{F}, K_{t}\right\}$. The Treasury's policy is captured by the choices of taxation and debt issuance $\left\{T_{t}, B_{t}\right\}{ }^{32}$ The goal is to determine the price level $P_{t}$, as a function of these nine policy variables subject to the six equations above and a set of initial and terminal conditions. ${ }^{33}$ A policy regime is a choice of which of these policy variables are exogenously chosen, and which must endogenously accommodate.

\subsection{The pre-crisis policy regime}

For most of the last twenty years, the press releases and commentary following meetings of the FOMC have focused on the current choice of innovations to the short-term interest rate, $x_{t}$, as well as its likely path in the future. Combining equations (11) and (16) and solving forward, the unique bounded solution for the price level is

$$
\Delta \ln \left(P_{t}\right)=\frac{\ln (\beta)}{1-\chi}+\sum_{j=0}^{\infty} \chi^{-j-1}\left[\Delta \ln \left(C_{t+1+j}\right)-x_{t+1+j}\right]
$$

Regardless of any other policy choice, interest-rate policy alone determines inflation. As long as the other policy choices respect the constraints imposed by the equilibrium in (11)-(16), understanding and forecasting inflation involves focusing solely on the target rates announced by the FOMC. Independently of how the other variables are determined, it is the Federal Funds rate that determines inflation, according to the model

Turning to the other variables, the policy rule in (16) determines endogenously the

\footnotetext{
${ }^{31}$ Adding a real activity to make this rule close to the Taylor rule would not change anything in the analysis.

${ }^{32}$ Outside of the model, the distinction between fiscal and monetary policy has become blurred by the recent events.

${ }^{33}$ The initial conditions are $M_{t-1}, B_{t-1}^{F}, B_{t-1}, \quad K_{t-1}$, and the terminal conditions come from consumer optimization with no outside assets and non-negative holdings of money and bonds: $\lim _{j \rightarrow \infty} \beta^{j} u^{\prime}\left(C_{t+j}\right) B_{t+j}^{P} / P_{t+j}=0$ and $\lim _{j \rightarrow \infty} \beta^{j} u^{\prime}\left(C_{t+j}\right) M_{t+j} / P_{t+j}=0$.
} 
observed short-term interest rate $i_{t}$. The other exogenous interest rate is $i_{t}^{m}$, which before October 2008 was zero. The money demand equation (12) then implied that total reserves $M_{t}$ were determined endogenously. Therefore, there was no independent quantitative policy, as the size of the Federal Reserve's balance sheet had to accommodate the fluctuations in the demand for reserves.

As for credit policy, before 2007, the Federal Reserve chose to have almost no private security holdings $\left(K_{t} \approx 0\right)$ and to hold government bonds roughly in line with the amount of reserves in circulation $\left(B_{t}^{F} \approx M_{t}\right)$. The Federal Reserve's budget constraint, equation (15), reduces to:

$$
V_{t} \approx i_{t-1} M_{t-1}
$$

approximately in steady state. With these policy choices, the Federal Reserve obtained a net income of seigniorage every period, rebating almost all of it to the Treasury to keep its accounting capital roughly constant.

Finally, turning to fiscal policy, combining the result in equation (18) with the Treasury's budget constraint in (13), the market clearing condition for bonds in (14), and the transversality conditions gives:

$$
\begin{aligned}
& B_{t}^{P}=P_{t}\left(G_{t}-T_{t}\right)+\left(1+i_{t-1}\right) B_{t-1}^{P}-\Delta M_{t}, \\
& \sum_{j=0}^{\infty}\left[\frac{P_{t+j}\left(T_{t+j}-G_{t+j}\right)+\Delta M_{t+j}}{\prod_{k=0}^{j}\left(1+i_{t-1+k}\right)}\right]=B_{t-1}^{P} .
\end{aligned}
$$

The fiscal authorities can choose a path for deficits subject to the intertemporal solvency constraint in (20), and the total amount of outstanding U.S. debt evolves endogenously to satisfy equation (19).

Monetary policy has been independent of fiscal policy in that the Federal Reserve chooses $x_{t}$ taking only its mandate into account, regardless of the fiscal choices of the Treasury. Fiscal policy is dependent on monetary policy insofar as changes in reserves will affect the flow of seigniorage to the Treasury but, since the term $\Delta M_{t+j}$ has in the history of the Federal Reserve been tiny relative to the size of operating surpluses $P_{t+j}\left(T_{t+j}-G_{t+j}\right)$, this dependence has been close to irrelevant. 
Until recently, both the independence of the central bank to set interest rates and control inflation as well as the accommodation of reserves to interest-rate policy, were seen as hallmarks of good monetary policy. ${ }^{34}$ Some have even argued that this policy regime partly explains the decline in macroeconomic volatility in the two decades before the crisis. ${ }^{35}$

\subsection{Is the pre-2007 status quo sustainable?}

The crisis has brought significant changes in monetary policy. However, by themselves these do not imply that the determination of the price level must be different than what was just described. According to the model, monetary policy can still choose independently the path for interest rates $\left\{x_{t}\right\}$, and this alone still suffices to determine current and future inflation.

The changes in policy only have to affect the other variables in the system. First, by now being able to pay interest on reserves, the central bank can choose exogenously either $i_{t}-i_{t}^{m}$, or the quantity of reserves $M_{t}$. Unlike before, when the interest on reserves was fixed at zero, the central bank may now wish to set a target for the amount of reserves in the market, as long as it adjusts $i_{t}^{m}$ accordingly. Moreover, if it continues the current policy of setting $i_{t}^{m}=i_{t}$, the central bank can also target any level of reserves above the satiation level $\left(M_{t} / P_{t}\right)^{*}$. This policy has at least two virtues. First, it allows the central bank to inject as much liquidity as necessary to sustain the efficient equilibrium described in the previous section. Second, it eliminates the implicit tax on reserves that existed before 2008 and that Friedman (1960), Friedman (1969), and Goodfriend (2002), among many others, had criticized well before the crisis for being inefficient.

Turning to credit policy, the Federal Reserve can gradually sell its private holdings of securities, receiving in return government bonds until again these are approximately equal to the amount of reserves. The only substantial change is that now, with the removal of the tax on reserves, the transfers to the Treasury become zero. Since they were small to start with, this should have no visible effect on government finances and fiscal policy. The balance sheet of the Federal Reserve can stay larger than before, with reserves beyond the

\footnotetext{
${ }^{34}$ See Woodford (2003) and Mishkin (2009).

${ }^{35}$ See, for instance, Ben Bernanke's speech on 2004/02/20.
} 
satiation level at whatever amount is supplied.

The announced intentions of the Federal Reserve are roughly consistent with the scenario I just described. The Federal Reserve has been firm in its commitment to set interest rates to control inflation and to maintain its independence. ${ }^{36}$ Moreover, there is no indication of reversing the decision to pay interest on reserves. And finally, the Federal Reserve has indicated that it would like to lower its holdings of private securities to as close to zero as possible as soon as it can. ${ }^{37}$

One source of uncertainty is what the Federal Reserve will do about quantitative policy in the aftermath of the crisis. The Federal Reserve has indicated that once possible, it would lower reserves and the size of its balance sheet. ${ }^{38}$ The theory in this and the previous sections suggests that this is unnecessary, as there is nothing wrong with keeping reserves at high levels. Importantly, this much higher level of reserves is not inflationary. Once the Federal Reserve started paying interest on reserves and eliminated the tax on reserves, the old money multiplier that linked reserves to the price level broke down.

\subsection{The capital and fiscal risk to the status quo}

The main risk to the previous scenario comes from the Federal Reserve's flow of funds in equation (13). Now that interest is paid on reserves, and that reserves have more than doubled, the term $i_{t-1}^{m} M_{t-1}$ can become significant as soon as $i_{t-1}^{m}$ increases from zero in tandem with the Federal Funds rate. Moreover, with the Federal Reserve holding a

\footnotetext{
${ }^{36}$ From the joint statement of the Federal Reserve and the Treasury on 2009/03/23: "The Federal Open Market Committee (FOMC) [...] determines monetary conditions in the United States, subject to its congressional mandate to foster maximum sustainable employment and stable prices. The Federal Reserve's independence with regard to monetary policy is critical for ensuring that monetary policy decisions are made with regard only to the long-term economic welfare of the nation." From the same statement: "Actions that the Federal Reserve takes, during this period of unusual and exigent circumstances, in the pursuit of financial stability, such as loans or securities purchases that influence the size of its balance sheet, must not constrain the exercise of monetary policy as needed to foster maximum sustainable employment and price stability"

${ }^{37}$ As vice-chairman Kohn put it in a speech in 2009/05/23: "An important issue with our nontraditional policies is the transition back to a more normal stance and operations of monetary policy as financial conditions improve and economic activity picks up enough to increase resource utilization. These actions will be critical to ensuring price stability as the real economy returns to normal."

${ }^{38}$ Bernanke (2009/04/03) stated: "We have a number of tools we can use to reduce bank reserves or increase short-term interest rates when that becomes necessary. [...] Many of our lending programs extend credit primarily on a short-term basis and thus could be wound down relatively quickly. [...] the Federal Reserve can conduct reverse repurchase agreements against its long-term securities holdings to drain bank reserves or, if necessary, it could choose to sell some of its securities."
} 
significant amount of private securities, it is possible that the return on these securities may be negative, lowering revenues by the amount $q_{t-1} K_{t-1} \cdot{ }^{39}$ How can the Federal Reserve make up for this budget shortfall?

There are two separate issues, one real and one illusory. Starting with the latter, if the Federal Reserve suffers significant losses on its portfolio, its accounting capital may become negative. If the Federal Reserve was a common company, this would mean that it was bankrupt, as liabilities would exceed its assets. However, the Federal Reserve is not a common company, because its liabilities are special. Negative capital is a problem for a common company because the creditors can all demand to be paid yet there aren't enough assets to do so. In the case of the Federal Reserve though, its two main creditors are currency holders and banks holding reserves (which can be made required by law). Neither can show up at the central bank and demand to be paid with assets. The Federal Reserve's liabilities are legal tender, so there cannot be a run of creditors on the Federal Reserve. The accounting capital of the Federal Reserve is a vacuous concept. If there is a concern, it is because, as Berriel and Bhattarai (2009) document, most central banks including the Federal Reserve, seem to worry about their capital. As they show, if the central bank worries about maintaining a target level of capital in its balance sheet, this will move the path of interest rates away from what would be desirable.

The real issue is whether there is a need for outside funds. The Federal Reserve has a budget constraint, which must hold as it does for any other agent. Rearranging equation (13):

$$
i_{t-1}^{m} M_{t-1}-q_{t-1} K_{t-1}=i_{t-1} B_{t-1}^{F}-\left(\Delta B_{t}^{F}+\Delta K_{t}\right)+\Delta M_{t}-V_{t}
$$

the issue is that the left-hand side may become large, requiring funds to come from the sources on the right-hand side. The five terms on the right-hand side of this equation give the five possible sources of funds. The first is the interest collected on the government bonds it holds. Because $i_{t-1} \geq i_{t-1}^{m}$, the budget shortfall coming from paying reserves is

\footnotetext{
${ }^{39}$ The Federal Reserve has repeatedly stated that it believes the risk of losses is negligible (Bernanke, 2009/01/13), because in most of its programs, it is taking AAA-rated securities as collateral and imposing significant haircuts. There is reason to be a little skeptical. First, if the investment were riskless, we would expect that private investors would not be so reluctant to make them. Second, there is a certain irony in appealing to the high ratings of the collateral when the financial crisis has been marked by suspicions about the value of collateral and the reliability of ratings agencies.
} 
at most equal to the interest rate times the difference between reserves outstanding and government securities held. Looking at the Federal Reserve's balance sheet on August 20, displayed in figure on panel $\mathrm{C}$ of table 1 , with an annual interest rate as high as $5 \%$, this can amount to just over $\$ 10$ billion dollars per year. ${ }^{40}$ If the Federal Reserve exchanges a few of its private assets for government securities, as it already plans to do by the end of the year, then it can reach the normal status were $B_{t}^{F}>M_{t}$ and the interest on reserves is more than covered by the interest received on government securities.

The danger therefore comes almost entirely from large losses on private assets. The second and third terms on the right of equation (21) show that the government can sell its assets, whether the government securities or the private assets, to cover these losses. This cannot go on forever, as the Federal Reserve will eventually run out of assets. But considering the over $\$ 2$ trillion dollars of assets that the Federal Reserve holds, it would take quite catastrophic losses for a sustained period of time before this happens. ${ }^{41}$

Another option is to print money or raise reserves, raising $M_{t}$. If the economy is already satiated with reserves, then this extra printing of money will have no effect on the macroeconomy, as banks will be happy to accept these extra reserves as payment. There is no private or social cost of creating excess and possibly idle reserves. ${ }^{42}$

Only the final option is more troublesome. To pay for its budget shortfall, the Federal Reserve may choose to rely on a steady stream of financing from the Treasury $\left(V_{t}<0\right)$. The financial independence of the Federal Reserve from Congress has been a guarantee of its overall independence. ${ }^{43}$ Once transfers from the taxpayer to the Federal Reserve must be regularly approved by Congress, political pressures on the setting of interest rates are inevitable. There is a real danger that this will lead to permanent increases in inflation

\footnotetext{
${ }^{40}$ This comes from multiplying 0.05 by the sum of bank reserves plus Treasury deposits minus securities held outright. This maps into the worst-case scenario where the Treasury closes its deposit account with the Federal Reserve, demanding $\$ 240.2$ billions of bonds to be given back. Excluding this possibility, then already $B_{t}^{F}>M_{t}$.

${ }^{41}$ Stella (2009) tries to quantify this risk and comes with a worst-case scenario of losses of $\$ 78$ billion on the existing assets.

${ }^{42}$ Note that this option relies on the existence of a finite satiation level in the demand for reserves, beyond which people are indifferent about the real money balances they hold. Otherwise, printing money would compromise the Federal Reserve's target for inflation.

${ }^{43}$ Indeed, conventional measures of central bank independence typically use budgetary independence from the legislative bodies as a pre-requesite (see the recent survey in Cukierman (2008)).
} 
in exchange for only short-lived boosts to output, as the U.S. economy falls in the timeinconsistency trap described in Kydland and Prescott (1977).

In the extreme, this loss of independence may even trigger a change in policy regime. In particular, take the scenario where Congress limits the fiscal plans of the executive branch by imposing a target for government debt as a ratio of GDP (or consumption): $B_{t} / C_{t}$. The Treasury could accommodate this target by cutting deficits. But, as an alternative, it may choose a value for nominal deficits exogenously, and this is consistent with an equilibrium. ${ }^{44}$ The equilibrium price level would be:

$$
P_{t}=\frac{B_{t} / C_{t}}{\sum_{j=1}^{\infty} \beta^{j}\left(T_{t+j}-G_{t+j}\right) / C_{t+j}}
$$

and inflation would be solely determined by the fiscal choices. The Federal Reserve would then be forced to accommodate these fiscal policies by effectively giving away control of the nominal interest rates, with $x_{t}$ determined endogenously to satisfy:

$$
x_{t}=\Delta \ln \left(P_{t+1}\right)-\chi \Delta \ln \left(P_{t}\right)+\Delta \ln \left(C_{t+1}\right)-\ln (\beta)
$$

This fiscalist determination of inflation requires the Treasury to be dominant over the Federal Reserve in setting policy — the literature has called it the fiscal authorities being active and the central bank passive. ${ }^{45}$

\section{Interpreting the Federal Reserve's actions: interest-rate policy}

Regarding interest-rate policy, a key feature of the crisis of 2007-09 is that short-term interest rates have been almost zero. This is only the second time that this has happened in the last century in the United States, the other being the period of the Great Depression in the 1930s. Many economists refer to it as a "liquidity trap," since zero is the lowest

\footnotetext{
${ }^{44}$ This mechanism is described in Sims (1994) and Woodford (1995), and is discussed and criticized in Canzoneri et al. (2001) and Bassetto (2008).

${ }^{45}$ For further exploration of the implications of this fiscal theory of the price level within the crisis context, see Sims (2009) and Cochrane (2009).
} 
possible target for the Federal Funds rate, and transitory increases in the money supply lead investors that are indifferent between money and bonds to simply substitute one for the other. Conventional monetary policy appears to be powerless.

There is an extensive literature arguing that this appearance is incorrect. Motivated by the experience of the Japan in the 1990s, researchers over the past decade have characterized the challenges in a liquidity trap as well as some policy advice to confront them. ${ }^{46}$ Rather than being ineffective, choosing the right path for interest rates is particularly important during a liquidity trap.

To understand this point, recall the Fisher equation equating the real interest rate, $r_{t}$, to the nominal interest rate, $i_{t}$, minus expected inflation, $E_{t}\left(\Delta P_{t+1}\right)$ :

$$
r_{t}=i_{t}-E_{t}\left[\Delta \ln \left(P_{t+1}\right)\right]
$$

Moreover, recall that the (linearized) Euler equation with log utility for optimal consumption states that expected consumption growth between date $t$ and date $t+s$ is equal to the sum of short-term real interest rates across the two periods:

$$
E_{t}\left[\ln \left(C_{t+s}\right)-\ln \left(C_{t}\right)\right]=E_{t}\left(\sum_{j=0}^{s-1} r_{t+j}\right)
$$

Intuitively, the higher is the long-term real interest rate, which is equal to the expected path of the short-term real interest rates, the greater the incentive to save, postponing consumption today for consumption in the future.

The challenge for interest-rate policy is that the financial crisis and its spillover to the real economy have led to a fall in the real interest rate needed for the economy to respond efficiently. If inflation expectations remain stable and low, equation (24) may imply that the nominal interest rate would have to become negative to generate the needed real interest rate. Because this cannot happen, the nominal interest rate hits the zero lower bound, and

\footnotetext{
${ }^{46}$ This work in turn builds on earlier analyses of monetary policy during the Great Depression. Romer (1992), in particular, makes a compelling case for the powerful role of monetary policy in ending the Depression.
} 
real interest rates are too high. ${ }^{47}$ Equation (25) then implies that these excessively high real interest rates drive down current consumption, worsening the current recession.

The "Brookings answer" to this problem was given in two papers published in this series. First, Krugman (1998) emphasized that monetary policy is particularly potent in this time if it can steer inflation expectations. The way out of the trap is to raise inflation expectations in whatever way possible so that the short-term real interest rate can fall encouraging consumption. Then, Eggertsson and Woodford (2003) provided a practical way for affecting inflation expectations by noting that the Federal Reserve can commit to keep nominal interest rates low into the future, even after the shocks leading to the crisis has subsided. This would lower expected future short-term real interest rates, producing the desired fall in the long-term real interest rates that drives real activity up.

There are several other alternatives to raise inflation expectations, bring down real interest rates, and stimulate the economy. Devaluing the exchange rate is one, and another is to purchase government debt with a permanent increase in the money supply that again persists after the crisis has passed. A more institutional approach that would prevent the problem from appearing in the first place would be to announce a price-level target since this requires that current deflation is offset by expected future higher inflation to get back on the target. A final alternative is to commit to lower long-term nominal interest rates, as this is equivalent to committing to a lower path of short-term interest rates. ${ }^{48}$ It is important to note that these are not alternatives to the increase in inflation expectations achieved by committing to low nominal interest rates into the future. Rather, they are different ways to express the same policy in terms of its different consequences.

How do the Federal Reserve's actions compare to these theoretical suggestions? While the Federal Reserve has not announced a commitment to obtain higher inflation than average

\footnotetext{
${ }^{47}$ The nominal interest rate on any safe security cannot be negative because, selling this security short and keeping the proceeds as cash until the security matures, would give positive profits and an arbitrage opportunity. This is only approximately correct since the expected return on money is not exactly zero, but is slightly negative, as deposit accounts pay fees and cash held in pocket may be stolen. Still, it is likely very close to zero. Goodfriend (2000) and Buiter and Panigirtzoglou (2003) have revived an old proposal by Silvio Gesell for the government to tax money, effectively removing the lower bound on interest rates and therefore eliminating the possibility of liquidity traps.

${ }^{48}$ On exchange-rate policy see Svensson (2003), on debt purchases see Auerbach and Obstfeld (2005), on price-level targeting see Eggertsson and Woodford (2003), and on lowering long-term interest rates see Bernanke (2002).
} 
in the near future, in the way that a price-level target would suggest, it has announced its commitment to do what it can to prevent deflation. The FOMC announcements following every meeting in 2009 have stated the intention to keep the target for the Federal Funds rate at zero for an extended period of time. These are some signs that the advice of Krugman, Eggertsson and Woodford is being followed, although only half the way as the Federal Reserve has signaled that it will not tolerate either temporary or permanent above-normal inflation. ${ }^{49}$

At the same time, the other expressions of commitment to this policy are absent. First, announcing a devaluation of the exchange rate is not an option, since this is the domain of the Treasury, not the Federal Reserve. Second, there has been little purchasing of government debt, as the dollar value of Treasury-issued securities plus agency debt held by the Federal Reserve in August 2009 had only gone up to $\$ 847.9$ billions relative to $\$ 778.9$ billions in January of 2007. While the Federal Reserve has announced that it will expand the purchase of government bonds substantially in the coming months, it has also indicated that this might be temporary, as it returns to a balance sheet size similar to that in the past once the crisis subsides. Third, the change in the maturity composition of these securities to longer-term bonds is consistent with perhaps trying to lower long-term interest rates, but there is little evidence that this portfolio shift can have any effect on long-term interest rates beyond what the announcement of lower future short-term interest rates do.

A crucial part of the Federal Reserve's policy is its future actions after the crisis subsides, and these remain to be seen. In particular, the FOMC has not clearly stated that it will keep interest rates at zero even after the financial shock disappears, an important component of optimal policy according to the theory just discussed.

\section{Conclusion}

This paper provided a critical analysis of the Federal Reserve's policy actions in the past two years. It catalogued monetary policy into three groups, according to whether they affected interest rates, the size of the Federal Reserve's balance sheet, or the allocation of

\footnotetext{
${ }^{49}$ As clearly stated by vice-chairman Kohn on October of 2009.
} 
its credit across different assets.

With regards to its interest-rate policy, the Federal Reserve has followed the advice from theory by committing to fight deflation and to keep interest rates at zero for the foreseeable future. It has deviated from the theoretical recommendations by not committing to higherthan-average inflation in the future, and especially by not providing a clear signal that it will keep nominal interest rates low for some time even after the crisis is over.

With regards to quantitative policy, at least theoretically, there is no reason why the path of short-term nominal interest rates should stop determining inflation, or why the separation between monetary and fiscal policy would have to change. Both of these have been lauded as hallmarks of the successes in monetary policy in the past two decades. However, there is a danger brought by the combination of an expansion in the Federal Reserve's balance sheet, interest payments on reserves, and assets with risky returns. The Federal Reserve might face significant budget shortfalls, and over-reacting to these may lead to surrendering independence to fiscal policy, potentially compromising both of the hallmarks above.

Finally, regarding credit policy, I introduced a new model of the financial market's role in allocating funds subject to credit frictions. I considered the merit of different interventions according to the model and to alternative beliefs on the knowledge and power of the Federal Reserve. The model suggested that injecting funds into firms that trade asset-backed securities through senior loans is an effective way to intervene in the financial markets. Theoretically, this seemed superior to lending funds to the originators of loans or to buying securities directly, and perhaps even to taking equity stakes in financial firms. The Federal Reserve's actions over the past two years have included almost all of these alternatives. Perhaps this was wise, since we know so little in this area. More likely, looking back in a few years and using either the model in this paper or those that follow, some of the credit policies will be seen as ineffective or even harmful.

In spite of jumping across many different topics, models, and policies, I was not able to discuss all the facets of the crisis and of monetary policy. I have not considered aggregate risk and changes in risk spreads, nor the potential for bank runs. ${ }^{50}$ Likewise, I have not

\footnotetext{
${ }^{50}$ On risk spreads, see Curdia and Woodford (2009), and on bank runs see Allen et al. (2009).
} 
discussed the role of foreign investors and the external deficit, nor have I compared the Federal Reserve's actions with those of other central banks around the world. Finally, I did not emphasize the political economy trade-offs that the different policies involve, and which may become important in the near future.

Writing this interpretation of the Federal Reserve's actions came with the privileges of being selective and of having some hindsight. Neither of the two were available to the Federal Reserve and other central banks in the past two years. Moreover, as is almost always when an academic writes about policy, the tone and spirit of this interpretation of the Federal Reserve's actions is based on the premise that theory is ahead of practice. The events of the past two years have been sufficiently humbling for academics like me, that we must be less confident on this premise than usual. 


\section{Appendix}

This appendix complements the setup and solution of the model in the main text.

\section{A.1. The problem of the representative consumer/worker}

Her problem is to:

$$
\begin{aligned}
& \max C^{\prime \prime}, L^{S}, L^{S \prime}, L^{S \prime \prime} \\
\text { s.t. } \quad: & \int_{0}^{N} P_{i}^{\prime \prime} C_{i}^{\prime \prime}+H^{\prime \prime}=W\left(L^{S}+L^{S \prime}+L^{S \prime \prime}\right)+\text { Payoff, } \\
C^{\prime \prime}= & \left(\int_{0}^{N} C_{i}^{\prime \prime 1 / m} d i\right)^{m} .
\end{aligned}
$$

The first line gives the preferences of the agent. Utility is logarithmic in total consumption and linear in labor supplied; these functional forms serve the purpose of making the algebra easier.

The second line is the budget constraint. On the left-hand side are the uses of funds in the third period, to purchase the consumption good from the firms and to pay taxes $H^{\prime \prime}$. On the right-hand side are the sources of funds: wages received from labor and the payoff income received from the four financial participants in the last period. Because utility is linear in labor supply in the three periods, there is a single wage. Since capital is transferred across periods at zero net return, this is the single intertemporal budget constraint.

Finally, in the third line is the Dixit-Stiglitz aggregator mapping the consumption of different varieties into the final composite goods, with elasticity of substitution $m /(m-1)$.

The optimality conditions are:

$$
\begin{aligned}
1 & =\left(\int_{0}^{N} P_{i}^{\prime \prime 1 /(1-m)} d i\right)^{1-m}, \\
C_{i}^{\prime \prime} & =C^{\prime \prime} P_{i}^{\prime \prime m /(1-m)} \\
C^{\prime \prime} & =W .
\end{aligned}
$$

\section{A.2. The problem of the agents in the financial market}

Investors start in period 1 with capital $M$. Their budget constraints for each period 
are:

$$
\begin{aligned}
\operatorname{Inv}+H_{I} & =M, \\
I n v^{\prime}+H_{I}^{\prime}+S e c^{\prime} & =H_{I}, \\
H_{I}^{\prime \prime} & =H_{I}^{\prime}+\operatorname{Inv}+\operatorname{Inv}^{\prime}+(1-\phi) S e c^{\prime} / Q^{\prime} .
\end{aligned}
$$

In words, in the first period, they invest Inv in traders and keep $H_{I}$ in capital. In the second period, they invest an additional $I n v^{\prime}$, buy securities in amount $S e c$ and keep the remainder $H_{I}^{\prime \prime}$ in capital. In the third period, they receive back their previous investments to traders at zero net return, and receive the payoff of the $1-\phi$ securities they bought last period that happened to pay out, ending with a total amount of capital of $H_{I}^{\prime \prime}$.

Entrepreneurs start with capital $K$. The aggregate budget constraint (summed over all entrepreneurs) in each period is:

$$
\begin{aligned}
W F I+H_{E} & =K+\text { Loan }, \\
W L^{\prime} N+H_{E}^{\prime} & =\operatorname{Loan}^{\prime}+H_{E}, \\
W L^{\prime \prime} N+H_{E}^{\prime \prime} & =\delta P^{\prime \prime} Y^{\prime \prime} N+H_{E}^{\prime} .
\end{aligned}
$$

In the first period, entrepreneurs have their capital and the loans from lenders, and use this to pay the fixed costs, with $H_{E}$ left over. In the second period, they have this capital plus the new loans. They spend them on the operating costs of the firms and leave $H_{E}^{\prime}$ for next period. Finally, in the last period, they receive the share $\delta$ of revenue, and end with total capital $H_{E}^{\prime \prime}$.

The budget constraint of the lending sector on aggregate is:

$$
\begin{aligned}
L o a n+H_{L} & =D+S, \\
\operatorname{Loan}^{\prime}+H_{L}^{\prime} & =D^{\prime}+S^{\prime}+S e c^{\prime}+H_{L}, \\
(1-\phi) S / Q+S^{\prime} / Q^{\prime}+(1-\phi) S e c^{\prime} / Q^{\prime}+H_{L}^{\prime \prime} & =(1-\delta) N P^{\prime \prime} Y^{\prime \prime}+H_{L}^{\prime} .
\end{aligned}
$$

In the first period, lenders start with capital $D$ and obtain extra capital $S$ by selling secu- 
rities. They use this to make loans and hold a non-negative amount of capital $H_{L}$. The next period, they receive new capital, sell new securities to traders and investors, and can use the capital saved from last period. They use this capital to increase the loans through the credit lines and potentially to hold capital for the following period. Finally, in the last period, they receive a share $1-\delta$ of the revenues and, and must pay back the securities holders of the surviving firms.

Finally, turning to the traders' sector, the budget constraints on aggregate are:

$$
\begin{aligned}
S+H_{T} & =E+I n v, \\
S^{\prime}+H_{T}^{\prime} & =E^{\prime}+I_{n v^{\prime},} \\
\text { Inv }+ \text { Inv }{ }^{\prime}+H_{T}^{\prime \prime} & =(1-\phi) S / Q+S^{\prime} / Q^{\prime} .
\end{aligned}
$$

In the first period, traders buy securities $S$ and hold capital $H_{T}$. They have their starting funds $E$ and receive Inv from investors. The same applies in the second period, while in the third period, the investments are repaid at zero net cost, while the securities earn a non-zero return. The pledgeabillity constraints on investment are:

$$
\begin{aligned}
\text { Inv } & \leq(1-\mu) S \\
\text { Inv }^{\prime} & \leq(1-\mu)\left\{S^{\prime}+\left[(1-\phi) Q^{\prime}-Q\right] S / Q\right\} .
\end{aligned}
$$

The second term in the pledgeability constraint at date 2 is the capital gain on the securities bought in the previous period. The possible absconding of traders with the assets is not included in these constraints because this never happens in equilibrium.

The capital holdings for all agents have to non-negative: $H_{I}, H_{I}^{\prime}, H_{I}^{\prime \prime}, H_{E}, H_{E}^{\prime}, H_{E}^{\prime \prime}, H_{L}$, $H_{L}^{\prime}, H_{L}^{\prime \prime}, H_{T}, H_{T}^{\prime}, H_{T}^{\prime \prime}$ are all larger than or equal to zero.

\section{A.3. Optimality conditions for financial agents}

Each of the risk-neutral financial agents wants to maximize its final capital. I focus here on the case where in equilibrium, there is some inefficiency so $Q<1-\phi$, and $Q^{\prime}<1$. The other cases are similar.

Starting with investors, they want to maximize $H_{I}^{\prime \prime}$. As long as $Q^{\prime}>1-\phi$, then they 
will buy no securities, $S e c^{\prime}=0$, since these lead to a negative return. Moreover, they are indifferent between holding capital of giving it to traders, and I assume that they invest as much as they can, subject to the pledgeability constraint.

Entrepreneurs earn strictly positive profits. Therefore, the return of applying the capital in the firm is higher than keeping it idle, and $H_{E}=H_{E}^{\prime}=0$. The optimal number of projects started and labor hired is determined in section 3.3.

Moving to lenders, since they are willing to sell securities at a positive return to traders, they must not be holding capital at zero return, so $H_{L}=H_{L}^{\prime}=0$. The optimal choice of Loan and Loan' was determined in section 3.3, and the optimal issue of $S$ and $S^{\prime}$ were stated in section $3.4 \mathrm{~m}$, and come from the budget constraints.

Traders earn a positive net return on the securities. Since capital earns a zero return, they choose $H_{T}=H_{T}^{\prime}=0$. Since they pay zero return to investors, they will want to draw as many funds from them as possible. The pledgeability constraints therefore hold with equality. Combining the pledgeability and budget constraints gives the demand for securities in the text, $S=E / \mu$ and $S^{\prime}=E^{\prime} / \mu+[(1-\mu) / \mu]\left[(1-\phi) Q^{\prime} / Q-1\right] E / \mu$.

\section{A.4. Market clearing conditions and Walras law}

Start by summing the budget constraints for the four financial agents, in order to obtain the market clearing conditions for capital within the financial market. This gives:

$$
\begin{aligned}
H_{I} & =M+K+D+E-W F I \\
H_{I}^{\prime} & =H_{I}+D^{\prime}+E^{\prime}-W L^{\prime} N \\
H_{I}^{\prime \prime}+H_{E}^{\prime \prime}+H_{L}^{\prime \prime}+H_{T}^{\prime \prime} & =N P^{\prime \prime} Y^{\prime \prime}-N W L^{\prime \prime}+H_{I}^{\prime} .
\end{aligned}
$$

The first two conditions determine the capital left over with investors at the end of the first two periods. They show that as long as $M$ is large enough, $H_{I}>0$ and $H_{I}^{\prime}>0$, an assumption that I maintain throughout the analysis. This in turn translates into an assumption on total initial capital, since the market clearing condition for capital between the representative household and financial institutions in the first period is:

$$
H=M+K+D+D^{\prime}+E+E^{\prime}
$$


The payoff from financial firms to households in the last period is:

$$
\begin{aligned}
\text { Payoff } & =H_{I}^{\prime \prime}+H_{E}^{\prime \prime}+H_{B}^{\prime \prime}+H_{L}^{\prime \prime} \\
& =P^{\prime \prime} Y^{\prime \prime} N-W L^{\prime \prime} N+H_{I}^{\prime} \\
& =P^{\prime \prime} Y^{\prime \prime} N-W L^{\prime \prime} N-W L^{\prime} N-W F I+H .
\end{aligned}
$$

where the second equality comes from the market clearing condition for capital in the third period, and the third equality from using the market-clearing conditions in the other periods.

Noting that market clearing in the goods market implies that $\int_{0}^{N} P_{i}^{\prime \prime} C_{i}^{\prime \prime} d i=P^{\prime \prime} Y^{\prime \prime} N$, we can re-write this last expression as:

$$
\int_{0}^{N} P_{i}^{\prime \prime} C_{i}^{\prime \prime}+H=W F I+W L^{\prime} N+W L^{\prime \prime} N+\text { Payoff }
$$

Finally, since the labor market clearing conditions are: $F I=L^{S}, L^{\prime} N=L^{S \prime}$, and $L^{\prime \prime} N=$ $L^{S \prime \prime}$, this expression becomes the budget constraint of the representative consumer. This verifies Walras law and confirms that all funds have been accounted for.

\section{References}

Allen, Franklin, Ana Babus, and Elena Carletti (2009), "Financial crises: Theory and evidence." University of Pennsylvania, manuscript.

Auerbach, Alan J. and Maurice Obstfeld (2005), "The case for open-market purchases in a liquidity trap." American Economic Review, 95, 110-137.

Bassetto, Marco (2008), "Fiscal theory of the price level." In The New Palgrave: A Dictionary of Economics (Lawrence Blume and Steven Durlauf, eds.), MacMillan, London.

Bernanke, Ben (2002), "Deflation: Making sure 'it' doesn't happen here." Remarks before the National Association of Economists, 11/21.

Berriel, Tiago and Saroj Bhattarai (2009), "Monetary policy and central bank balance sheet concerns." Contributions to Macroeconomics, 9, 1. 
Blanchard, Olivier J. (2009), "The crisis: Basic mechanisms, and appropriate policies." MIT working paper 09-01.

Brunnermeier, Markus K. (2009), "Deciphering the 2007-08 liquidity and credit crunch." Journal of Economic Perspectives, 23, 77-100.

Buiter, Willem H. and Nikolaos Panigirtzoglou (2003), "Overcoming the zero bound on nominal interest rates with negative interest on currency: Gesell's solution." Economic Journal, 113, 723-746.

Canzoneri, Matthew, Robert Cumby, and Behzad Diba (2001), "Is the price level determined by the needs of fiscal solvency?" American Economic Review, 91, 1221-1238.

Cecchetti, Stephen G. (2009), "Crisis and responses: The federal reserve in the early stages of the financial crisis." Journal of Economic Perspectives, 23, 51-75.

Cochrane, John (2009), "Fiscal theory, and fiscal and monetary policy in the financial crisis." University of Chicago, manuscript.

Cukierman, Alex (2008), "Central bank independence and monetary policymaking institutions - past, present and future." European Journal of Political Economy, 24, 722-736.

Curdia, Vasco and Michael Woodford (2009), "Conventional and unconventional monetary policy." Columbia University, manuscript.

Eggertsson, Gauti B. and Michael Woodford (2003), "The zero bound on interest rates and optimal monetary policy." Brookings Papers on Economic Activity, 34, 139-235.

Friedman, Milton (1960), A Program for Monetary Stability. Fordham University Press.

Friedman, Milton (1969), The Optimum Quantity of Money and Other Essays. Aldine.

Goodfriend, Marvin (2000), "Overcoming the zero bound on interest rate policy." Journal of Money, Credit, and Banking, 32, 1007-1035.

Goodfriend, Marvin (2002), "Interest on reserves and monetary policy." Economic Policy Review, 8, 1-8. 
Gorton, Gary (2009), "Information, liquidity, and the (ongoing) panic of 2007." American Economic Review, 99, 567-572.

Greenlaw, David, Jan Hatzus, Anil Kashyap, and Hyun Song Shin (2008), "Leveraged losses: Lessons from the mortgage market meltdown." U.S. Monetary Policy Forum Report 02.

Holmstrom, Bengt and Jean Tirole (2009), Inside and Outside Liquidity. Wicksell lectures book in preparation.

Kiyotaki, Nobuhiro and John H. Moore (1997), "Credit cycles." Journal of Political Economy, 105, 211-248.

Krishnamurthy, Arvind (forthcoming), "Amplification mechanisms in liquidity crises." American Economic Journal: Macroeconomics.

Krugman, Paul R. (1998), "It's baaack: Japan's slump and the return of the liquidity trap." Brookings Papers on Economic Activity, 29, 137-206.

Kydland, Finn E. and Edward C. Prescott (1977), "Rules rather than discretion: the inconsistency of optimal plans." Journal of Political Economy, 85, 473.

Matsuyama, Kiminori (2007), "Aggregate implications of credit market imperfections." NBER Working Papers 13209.

Mishkin, Frederic S. (2009), Monetary Policy Strategy. The MIT Press.

Reis, Ricardo (2007), "The analytics of monetary non-neutrality in the sidrauski model." Economics Letters, 94, 129-135.

Reis, Ricardo (2009), "Where should liquidity be injected during a financial crisis?" Columbia University, manuscript.

Romer, Christina D. (1992), "What ended the great depression?" Journal of Economic History, 52, 757-784.

Shleifer, Andrei and Robert W. Vishny (2009), "Unstable banking." NBER working papers 14943. 
Sims, Christopher A. (1994), "A simple model for study of the determination of the price level and the interaction of monetary and fiscal policy." Economic Theory, 4, 381-399.

Sims, Christopher A. (2009), "Price level determination in general equilibrium." Society for Economic Dynamic Annual Meeting plenary talk.

Stella, Peter (2009), "The federal reserve system balance sheet-what happenned and why it matters." IMF Working Papers.

Svensson, Lars E. O. (2003), "Escaping from a liquidity trap and deflation: The foolproof way and others." Journal of Economic Perspectives, 17, 145-166.

Woodford, Michael (1995), "Price-level determinacy without control of a monetary aggregate." Carnegie-Rochester Conference Series on Public Policy, 43, 1-46.

Woodford, Michael (2003), Interest and prices: foundations of a theory of monetary policy. Princeton University Press.

Woodford, Michael (2008), "How important is money in the conduct of monetary policy?" Journal of Money, Credit and Banking, 40, 1561-1598. 
Figure 1. Interest rates targeted by the Federal Reserve, 1989:8-2009:8

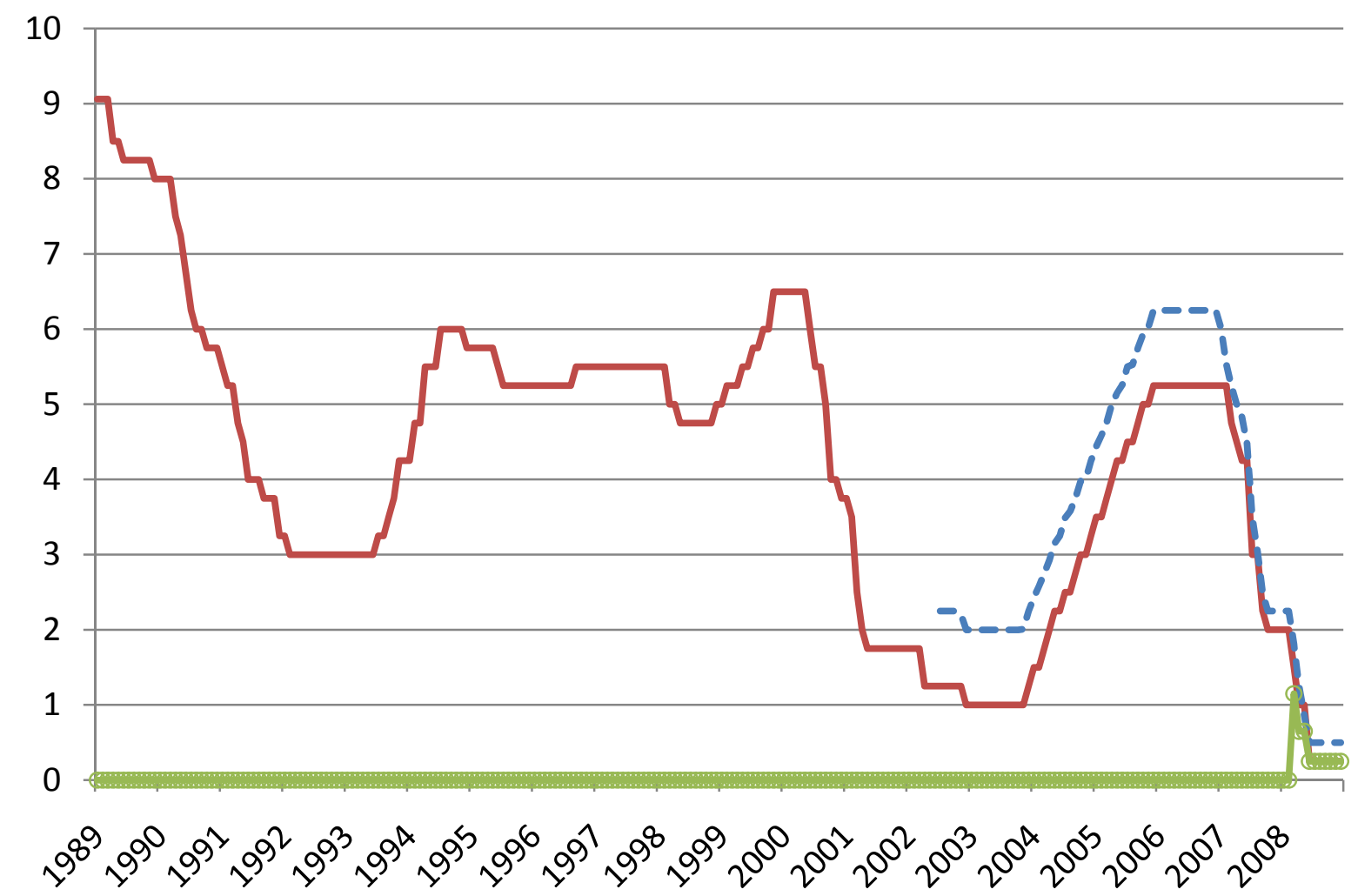

Federal Funds rate $\_-$Discount rate $\multimap$ Interest on reserves 
Figure 2. Adjusted reserves and monetary base as ratio of annual GDP, 1929-2009

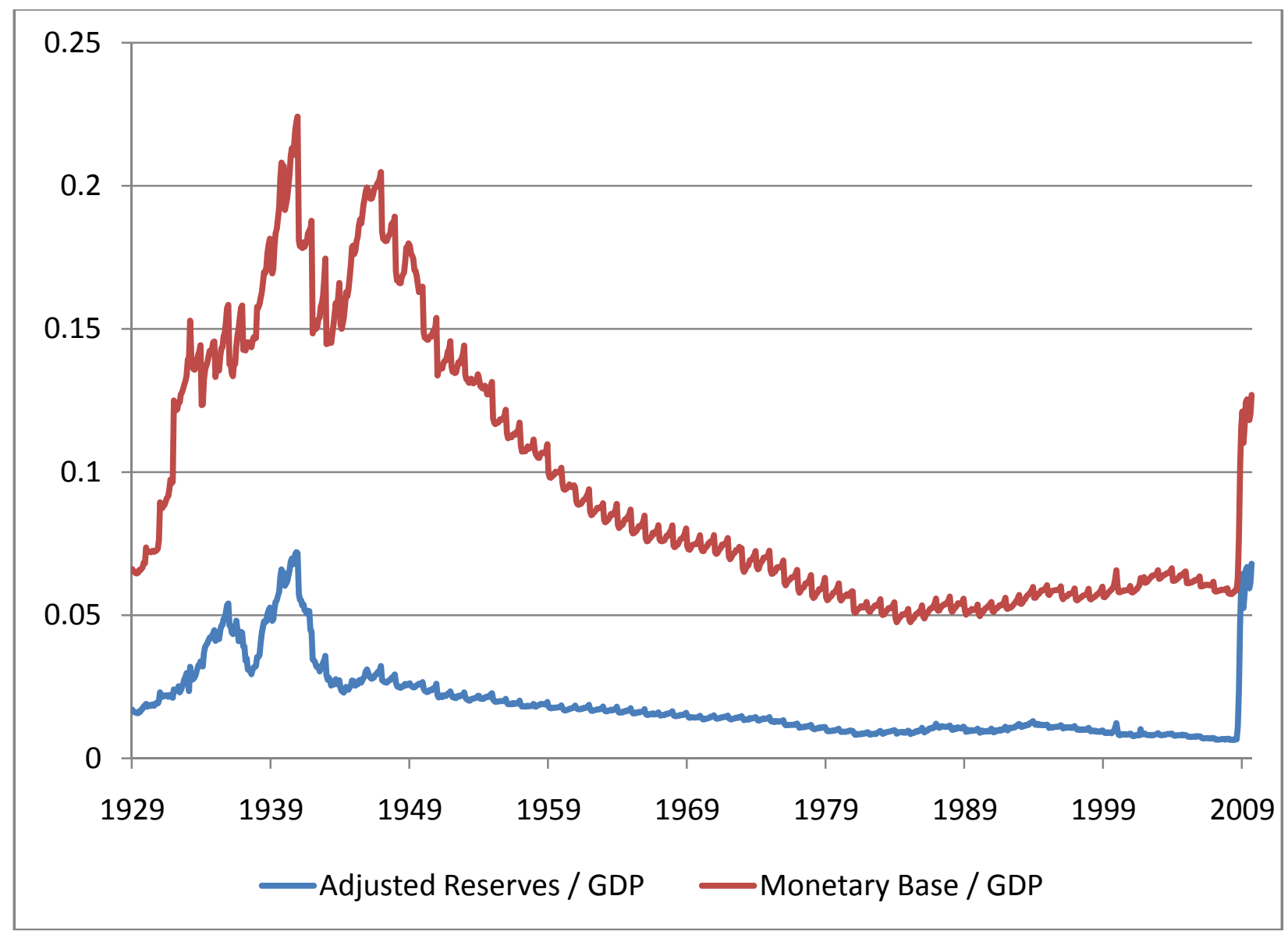


Figure 3. Treasury securities held outright divided by total assets, 1996:6-2009:8

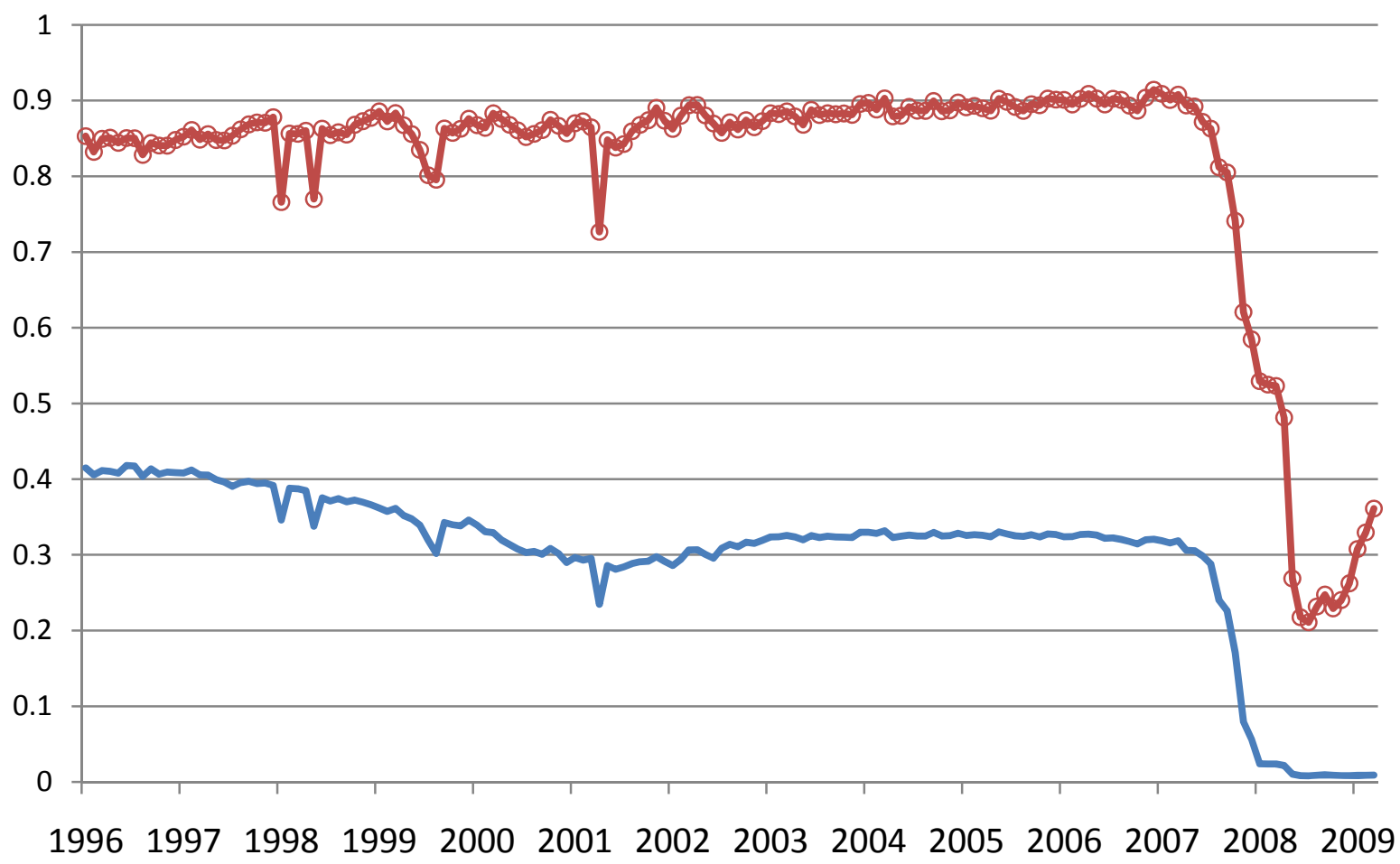

—Share of assets in Treasury bills

$\multimap$ Share of assets in Treasury securities (bills, bonds and notes) 
Table 1. Three snapshots at the actions of the Federal Reserve

Panel A. January, 4, 2007

Federal Funds Target Rate: 5.25\%

Balance Sheet (in billions of dollars)

\begin{tabular}{l|l||l|l}
\hline Assets & & Liabilities & \\
\hline Securities held outright & & Federal Reserve notes & 781.3 \\
U.S. Treasury bills & 277.2 & Commercial bank reserves & 20.0 \\
U.S. Treasury notes and bonds & 501.7 & U.S. Treasury deposits & 6.2 \\
Agency Debt & 0 & Reverse repurchase agreements & 29.7 \\
Repurchase Agreements & 39.8 & Others & 12.3 \\
Direct Loans & 1.3 & & \\
Gold & 11.0 & Total liabilities & 847.9 \\
Foreign reserves & 20.5 & & \\
Other Assets & 27.0 & & \\
& & & \\
Total Assets & 878.5 & Capital & 30.6 \\
\hline
\end{tabular}

Panel B. January, 2, 2009

Federal Funds Target Range: $0-0.25 \%$

Balance Sheet (in billions of dollars)

\begin{tabular}{l|l||l|l}
\hline Assets & & Liabilities & \\
\hline Securities held outright & & & \\
U.S. Treasury bills & 18.4 & Federal Reserve notes & 853.2 \\
U.S. Treasury notes and bonds & 457.5 & Commercial bank reserves & 860.0 \\
Agency debt & 19.7 & U.S. Treasury deposits & 365.4 \\
Repurchase Agreements & 80.0 & Reverse repurchase agreements & 88.3 \\
Direct Loans & 193.9 & Others & 56.9 \\
Gold & 11.0 & & \\
Foreign reserves & 579.8 & Total liabilities & \\
Other assets & 47.4 & & \\
New asset categories & & & \\
Term Auction Facility (TAF) & 450.2 & & \\
Commercial Paper FF & 334.1 & & \\
Maiden Lane & 73.9 & & \\
Total Assets & 2265.9 & Capital & \\
\hline
\end{tabular}


Panel C. August, 20, 2009

Federal Funds Target Range: $0-0.25 \%$

Balance Sheet (in billions of dollars)

\begin{tabular}{l|l||l|l}
\hline Assets & & Liabilities & \\
\hline Securities held outright & & & \\
U.S. Treasury bills & 18.4 & Federal Reserve notes & 871.5 \\
U.S. Treasury notes and bonds & 717.7 & Commercial bank reserves & 818.8 \\
Agency debt & 111.8 & U.S. Treasury deposits & 240.2 \\
Repurchase Agreements & 0 & Reverse repurchase agreements & 68.4 \\
Direct Loans & 106.3 & Others & 14.4 \\
Gold & 11.0 & & \\
Foreign reserves and other assets & 76.7 & Total liabilities & 2013.3 \\
New asset categories & & & \\
Term Auction Facility (TAF) & 221.1 & & \\
Commercial Paper FF & 53.7 & & \\
Maiden Lane & 61.7 & & \\
Mortgage-backed securities & 609.5 & & \\
Central Bank liquidity swaps & 69.1 & & \\
& & & \\
Total Assets & 2063.8 & Capital & \\
\hline
\end{tabular}

Sources: Board of Governors of the Federal Reserve System, Table H4.1 and Federal Reserve Bank of New York Quarterly Report on foreign exchange operations. 
Figure 4. Agents and markets in the model of credit frictions

Panel A. Timing

Second period flow of funds:

Lenders $\rightarrow>$ Entrepreneurs (credit lines)

Traders -> Lenders (securities market)

Investors -> Traders (leverage over capital gains)

Investors -> Lenders (if $Q^{\prime}=1-\phi$ )

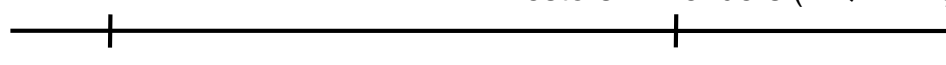

First period flow of funds:

Lenders -> Entrepreneurs (loan for set-up costs)

Traders $\rightarrow>$ Lenders (securities market)

Investors -> Traders (leverage)
Third period flow of funds:

Entrepreneurs -> Lenders (loans repaid) Lenders -> Traders (securities mature) Lenders -> Investors (securities mature) Traders $->$ Investors (leverage repaid)

All agents -> representative household (initial capital and profits)

$\underline{\text { Panel B. Markets }}$

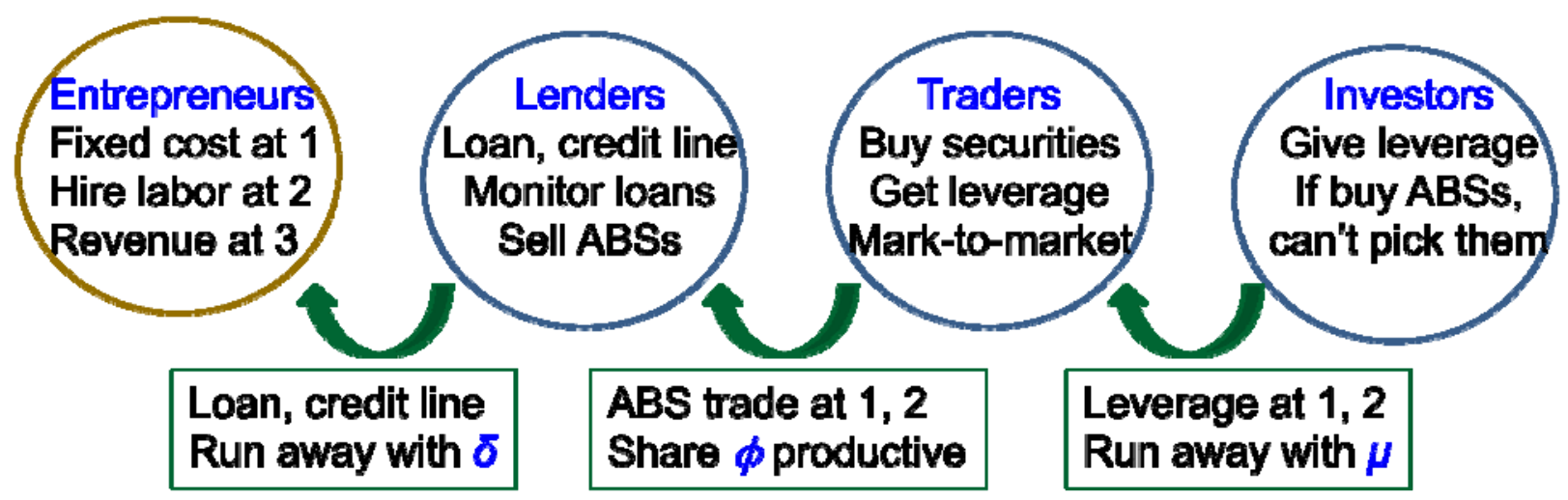


Figure 5. Equilibrium in a constrained economy

Top panel: First-period market

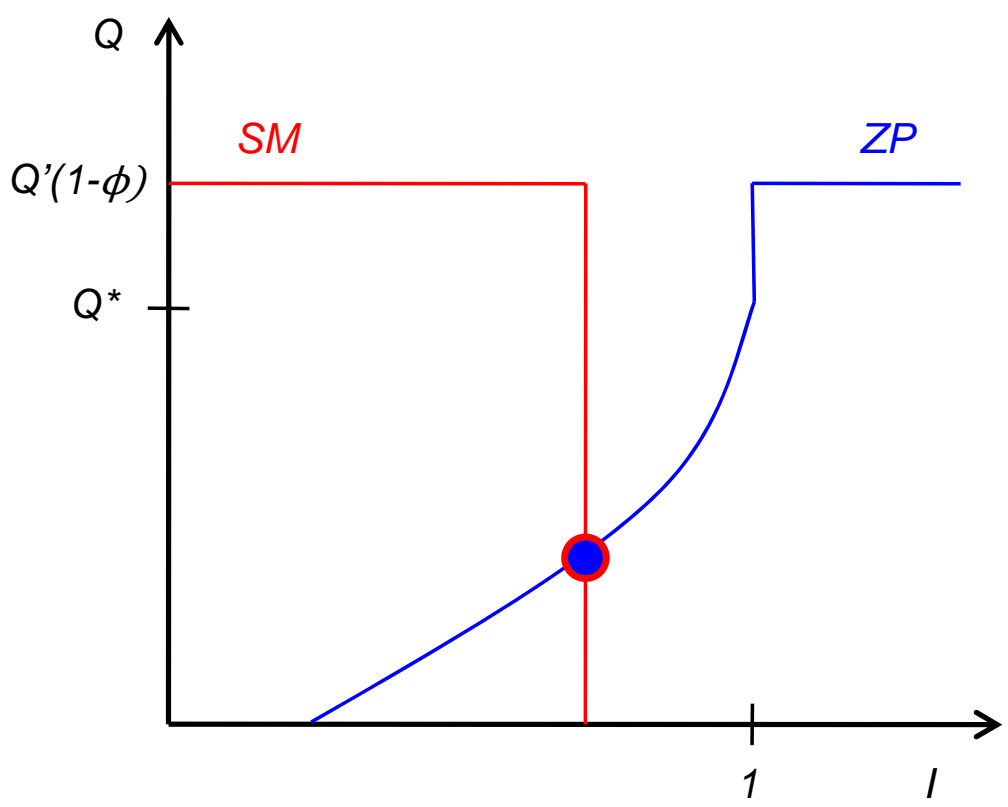

Bottom panel: Second-period market

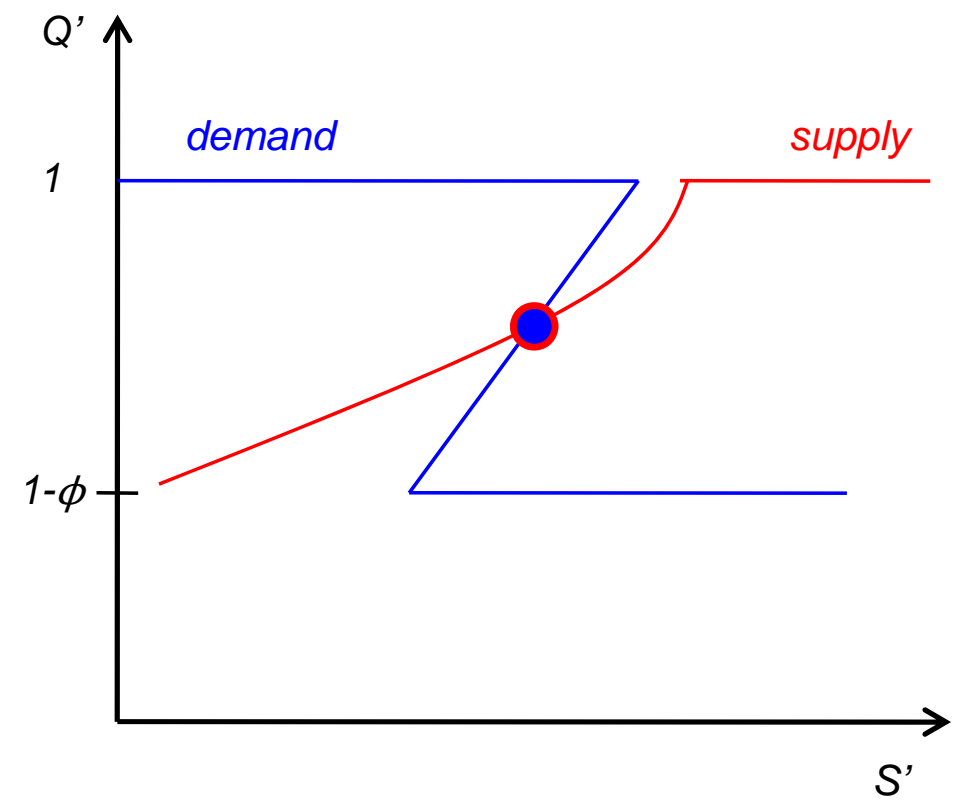


Figure 6. Injecting credit via loans to lenders and traders (first-round effects)

Top panel: First-period market

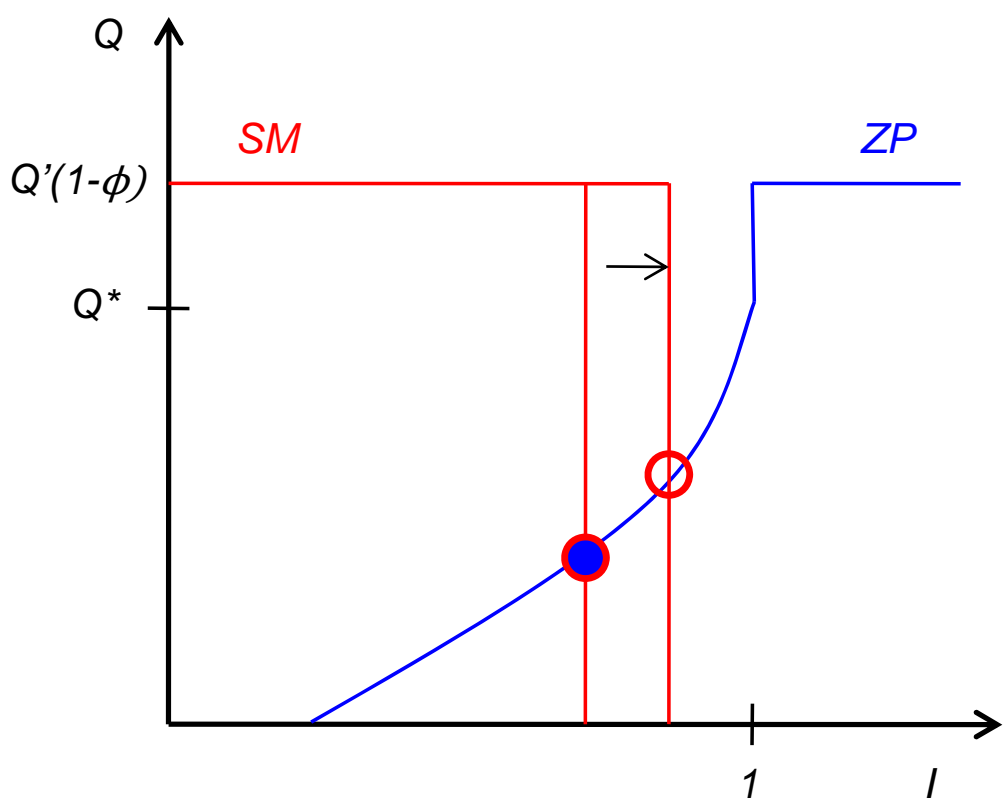

Bottom panel: Second-period market

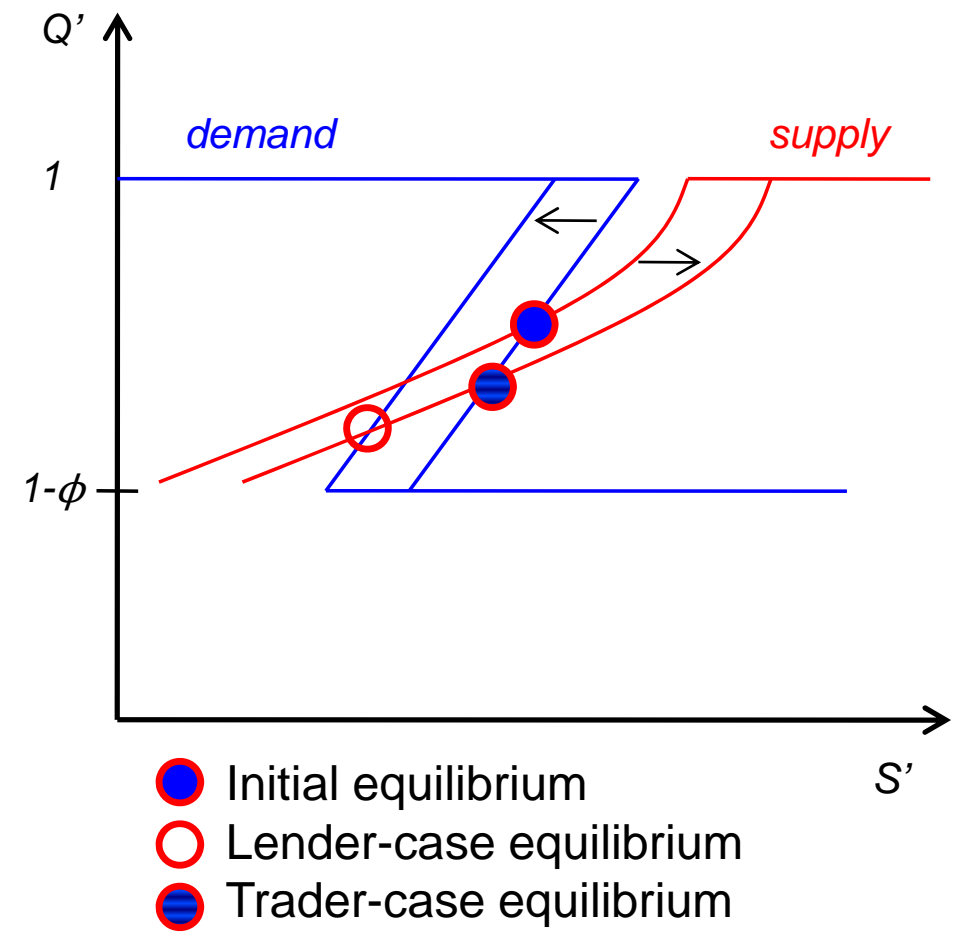

